\title{
Kırık Sacayağını Onarmak: Edebî Eleştiride Yazar, Metin ve Okur
}

\begin{abstract}
Alphan AKGÜL*
Öz

Edebiyat incelemelerinde yazar, metin ve okur arasındaki ilişkiler sorgulanırken bu üç ögeyi birbirinden ayırmak, birini ötekine göre daha üstün tutmak sık karşılaşılan yaklaşımlardan biridir. Romantikler yazarı yüceltirken modernistler yazarı bir kenara koyup metni yüceltmişlerdir. Postmodern kuramlarda ise okurun öne çıkarıldığını, okur olmaksızın metnin bir anlam ifade etmeyeceğini savunan görüşlerin ağırlık kazandığ1 görülür. Metni bir kenara koyup yazarın hayatına odaklanmak ne kadar hatalıysa, metindeki biyografik ögeleri görmezden gelmek de aynı şekilde hatalı olabilir. Okura sınırsız yorum olanakları bahşedip metnin sınırlı ama anlamlı yorum olanaklarını görmezden gelmek de yetersiz bir yoruma neden olabilir. Aynı şekilde okurun yaratıcı hayal gücünü bastırıp metnin anlam olanaklarını daraltmak da kusurlu bir yaklaşım olabilir. Bu makale, yazar, metin ve okur arasındaki ilişkinin edebiyat olayının sacayakları olduğunu öne sürmektedir. Bir edebiyat eseri ancak bu üç ögenin bir arada var olmasıyla gerçeklik kazanabilir. Bu yüzden edebiyat incelemelerinde bu ögelerden birini öne çıkarıp diğerini önemsiz görmek, edebiyat olayının dinamiklerini çökertebilir. Bir metinde biyografik özellikler, bir başka metinde dil ve üslup özellikleri, bir başka metinde ise okurun yaratıcı çıkarımları ağırlık kazanabilir ama bütün bunlar yazar, metin ve okur arasındaki dinamik ilişkinin parçaları olarak değerlendirilmelidir.
\end{abstract}

Anahtar Kelimeler: eleştiri, metin, yorum, okur, aşırı yorum

* Dr. Öğretim Üyesi, İstanbul 29 Mayıs Üniversitesi, Edebiyat Fakültesi, Türk Dili ve Edebiyatı Bölümü, Türkiye. Elmek: alphanakgul@gmail.com https://orcid.org/0000-0002-2381-0247 


\title{
REPAIRING THE BROKEN PILLAR: AUTHOR, TEXT AND READER IN LITERARY CRITICSM
}

\begin{abstract}
While questioning the relations between the author, the text and the reader in literature studies, it is a common approach to distinguish these three elements from each other and to keep one higher than the other. While romantics glorify the writer, modernists put aside the writer and glorify the text. In postmodern theories, it is seen that the reader is emphasized and the views that argue that the text will not make sense without the reader gain weight. Just as it is wrong to put the text aside and focus on the life of the author, it may be equally wrong to ignore the biographical elements in the text. Giving the reader limitless possibilities for interpretation and ignoring the limited but meaningful possibilities of interpretation of the text can also be an inadequate interpretation. Likewise, suppressing the creative imagination of the reader and narrowing the possibilities of meaning of the text may be a flawed approach. This article suggests that the author, the text and the reader are the pillars of a literary event. A literary work can only be realized by the combination of these three elements. For this reason, highlighting one of these elements in literature studies and seeing the other insignificant may disrupt the dynamics of the literary event. Biographical features in one text, language and style features in another text, and the creative implications of the reader in another text may gain weight, but all these should be considered as part of the dynamic relationship between the author, the text and the reader.
\end{abstract}

Keywords: criticism, text, interpretation, reader, overinterpretation 


\section{Extended Summary}

In text studies, it is always debated whether the center of gravity is the writer, text or reader. In classical criticism, such as tragedies, there is no method of criticism separate from the structural features of the text (i.e. Aristotle's Poetics). Similarly, in the critique of Ottoman Classical Poetry, the possibilities of the meaning of the text have been determined by the tradition.

In the nineteenth and twentieth centuries, drastic changes took place in text criticism, along with massive class and social transformations. Romantics see the author as a genius different from ordinary people. Poetry is the occupation of chosen people with special sensibilities. The poet has a sensitive soul, so he can sense the mystery of the universe and he can put these into his poems. This approach is a symbol of emerging individualism, but the modern world of the twentieth century begins to seek an objectivity in every field. Since moderns assumed that every discipline should have scientific criteria, they also made efforts for poetry studies to gain an objective perspective. Thus, new methods of text criticism were proposed to interpret individualistic and difficult poems expressing the concerns of the modern world. The writer and the reader had no place in textual criticism. The reader has become a device that explores the limited possibilities of meaning in that text by simply following the implicit instructions in the text.

Since the middle of the twentieth century, however, the idea of objectivity began to be questioned. The individual's perspective could not be displaced by the criterion of objectivity because, in this view, there was no objectivity other than the individual's comprehension. As this idea gained weight, "the reader" gained importance. The predominant role of the reader in text criticism led to the conclusion that the text was nothing but the reader's opinion. This reader-oriented criticism can eliminate the autonomous identity of the text. Umberto Eco makes a distinction between interpretation and overinterpretation in criticism of the text in order to save the autonomous identity of the text. The text can have multiple meanings, but this point of view does not mean that a text 
can have unlimited meaning. According to Eco, there are limits that should not be exceeded when analyzing a text. The reader's unlimited imagination should not work independently from the possibilities of the text's meaning.

When moving from the theoretical world to the application world, all of these perspectives can gain functionality. Poetry can be studied theoretically, but it does not fit well within a certain theoretical framework, because poetry does not have an exact definition, and every poem of the poetic universe can has their own character. Therefore, in each poem, the author, reader and structural text features have a separate role and a separate function. In a poem the author's biography can play a dominant role; to evaluate this poem independently of the author's biographical features may be seen as a critic's mistake. As a matter of fact, İlhan Berk's poem "Going to See the Wife of a Dead Poet" cannot be separated from İlhan Berk's visit to Huriye Necatigil, the wife of the poet, after the death of Behçet Necatigil. Berk's poem was triggered by a statement of Huriye Necatigil during this visit. The poem develops around this first line, as Berk also wrote an article describing how he wrote this poem by mentioning the details of the visit.

On the other hand, some poems also demand text-based criticism. Behçet Necatigil's "Kilim" is a perfect example which reveals the harmony between form and content so clearly that the critic Mehmet Kaplan must have immediately realized that he had to examine this feature of the poem. "Kilim" is a poem whose sound pattern is arranged cacophonously. The person speaking in the poem finds the age in which he lives irregular and chaotic. The rug, which is knitted with faults and tastelessness, is a metaphor for this meaning. Each sound

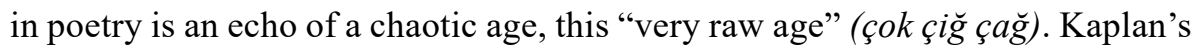
article examining the mimetic relationship between the meaning of poetry and the sounds that make up this meaning is a successful example of text-centered criticism.

What happens if excess is allowed in poetry interpretation? What if the reader is free in text criticism? If the reader is a trained critic or a creative reader, it may be possible to cross the predictable horizon of meaning of the text and to produce creative interpretations that can contribute to the culture of poetry. Undoubtedly, the freed reader may present examples of unsuccessful 
interpretation of poetry by making meaningless similarities, but vice versa. A comment may be based on a pattern derived from only a small portion of the text, but without these risks, a creative interpretation is unlikely to emerge. Necatigil's poem "Zar" is a poem full of actions that seem contradictory each other, but since the word "as if" is always used in this poem, there is actually no contradiction. A commentator who ignores the words "as if" may interpret the meaning pattern of this poem full of contradictions as a violation of the principle of the law of excluded middle. Yet the words "as if" are there; cannot be ignored. Nevertheless, such an interpretation reminds readers that poetry has a structure suitable for philosophical analysis. Perhaps it's not a bad thing for commentators to find the courage to make such inadequate comments. Innovation is often risky; critics who take risks may not be as harmful to the development of text criticism as it might seem. 



\section{Giriş}

Edebiyat eleştirisini nesnel ve bilimsel hale getirme konusundaki haklı çaba kimi örneklerde özneyi dışarıda bırakma tehlikesini içinde barındırır. Yorumlama faaliyeti söz konusu olduğunda bir metni onu üreten ve tüketen öznelerden soyutlama eğilimi, sanatsal edimin iki temel yönünü 1skalamak anlamına gelebilir. Metinler tek başlarına var olamazlar; üretilir ve tüketilirler. Bir metnin yazarı eserinin anlamına asla tam anlamıyla hâkim olamaz, olası yorumları bir çırpıda tahmin de edemez ama bütün bu öngörülemezliğe rağmen o eserin kaynaklandığı nokta, yazarın zihinsel faaliyetinin sözcüklere döküldüğü andır. Okur da bir metnin bütün olası yorumlarını icra edemez; duygusal sapmalarla çoğu kez metni yanlış da anlamlandırabilir ama buna karşın bir metin ancak bir okur tarafından yorumlanabilir. Çünkü bir okur tarafından okunmayan basılı bir eser, kuvveden fiile çıkartılmamış bir olası anlamlar manzumesinden başka bir şey değildir. Oysa on dokuzuncu yüzyılda yazarın, yirminci yüzyılda ise metin-merkezci yaklaşıma bir tepki olarak okurun öne çıkması, yani metnin dokusu yerine özneye aşırı vurgu yapılması, metin-merkezli eleştirinin yeniden tartışılmasına neden olmuştur. Bir metni yorumlarken sahne 1şıklarının altında sanatçının portresinden başka bir şey görünmüyorsa veya bütün metinler aynı okurun bakışları altında birbirine benzemeye başlamışsa, öznenin metin üzerinde, metnin dokusunu silip yok edecek ölçüde bir hükümranlık kurduğu söylenebilir. Ama tam tersi de tedirgin edicidir. Metni, yazar ve okurdan yalıtıp kendi başına anlam üreten bir makine gibi görmek, edebiyatın sacayaklarından ikisini kesmek anlamına gelebilir. Çünkü bir metin ancak öznelerin zihinlerinde varlık kazanır; doğada özneden bağımsız, özerk bir metin yoktur. Bu noktada unutulmaya yüz tutmuş bir bakış açısını hatırlatmakta fayda vardır: "Yazar", "metin" ve "okur"un birbirine görünmez iplerle bağlı olduğunu, yazarsız bir metnin, metinsiz bir okurun ve okursuz bir metnin olamayacağını söylemek, âdeta bir mahzene kapatılıp unutulmuş bir fikir olduğu hâlde, hâlâ işlevsel bir iddiadır, oysa bu iddia yorum üzerine yapılan tartışmaların sisli puslu havası 
içinde soluk almakta zorlanmakta, yeniden temiz havaya çıkartılmaya muhtaç görünmektedir. Okuma eylemi, yazar, metin ve okurun katıldığı diyalektik bir süreç olduğundan bu üç ögeden herhangi birine indirgenemez. Buna karşın eleştirel düşünce tarihten bağımsız olmadığı için belli dönemlerde yazara veya okura yapılan aşırı vurgular, metnin yazar ve okurdan uzak tutulması tepkisini doğurmuştur; tıpkı metne yapılan aşırı vurgunun metnin okurdan bağımsız hiçbir anlamı olamayacağı iddiasını doğurduğu gibi.

\section{Okuma Uğraşının Sacayağı: Yazar, Metin ve Okur}

Okuma eylemini ayakta tutan bir sacayağı vardır: Yazar, metin ve okur. Edebî geleneklerin karmaşık ve uzun tarihinde, bu ayakların birbirinden koparılması, hatta koparıldıktan sonra birbirlerinin karşısına birer rakip olarak çıkarılması şaşırtıcıdır. Çünkü bu üçlü aynı işleve sahip değildir; bir terkibin parçasıdırlar, bu nedenle de birbirlerine rakip olamazlar. Daha açık ifadeyle, ancak bir araya getirildiklerinde anlamlı bir bütündür bu parçalar. Oysa eleştiri tarihi, "yazar", "metin" ve "okur"dan birini öne çıkaran, okuma uğraşının sadece biri aracılığıyla etkin ve anlamlı olacağını iddia eden yaklaşımlarla doludur. Bize öyle geliyor ki bu parçalanmanın görünür olması yirminci yüzy1lın ilk çeyreğinde edebî okuma uğraşının yeniden ele alınmasıyla başlar. "Yeni Eleştiri” (New Criticisim) akımı, 1920 ve 30'lu yıllarda, on dokuzuncu yüzyıl edebiyat eleştirisinin kusurlu yönlerine odaklanarak bir "yakın okuma / yorumlama" (close reading) yöntemi geliştirir. Yeni Eleştiri, geleneksel eleştirinin üç yönüne itiraz etmektedir: Bunlardan ilki, yazarın üstün yeteneklerini kutsayan bir belle-lettrism, ikincisi okurun duygusal tepkilerine dayanan bir izlenimcilik, üçüncüsü ise tarihsel eleştiridir. ${ }^{1}$ Dikkat edilecek olursa, on dokuzuncu yüzy1l "metin" yerine, "yazar"a, "okur"a ve "tarih"e ağırlık vermiş; yani sacayağının birini eksik bırakmıştır. Romantik çağın yazarı kutsayan, onu âdeta bir kutlu kişi gibi gösteren düşünce sistemi, eleştirmenlerin yazarın biyografisine odaklanmalarına yol açmıştı. Bunun çarpıcı bir örneği şudur: Sansasyonel bir yaşamı olan ressam ve şair William Blake'in zeki ve öngörülü biri olması, siyasi tahminlerinin şaşırtıcı ölçüde doğru çıkması, hayranları tarafından şaire peygamberimsi ruhsal özellikler atfedilmesine neden olmuştur: 
Blake'de geleceği görme yeteneği söylentisi bir hayli yaygındı şairin hayranları arasında. Bu saçma bir savdı elbette. Onda geleceği görme yeteneği değil, herkesinkini kat kat aşan bir hayal gücü ve bir duyarlılık vardı sadece. Örneğin, küçükken babası onu Ryland adında bir gravürcüye götürmüş, oldukça ünlü olan bu adamın çırağı olmasını istemişti. Ama Blake adamın yüzünü beğenmemiş, onun eninde sonunda asılacağını söylemişti. Ve ne gariptir ki, on iki yıl sonra Ryland bir sahtekârlık yapmış, gerçekten asılmıştı. Gravürcünün kişiliğinde gizlenen kötülüğü, Blake'in çocukke+n bile hemen sezmesiyle açıklayabiliriz bu garip olayı. Daha sonraları Blake, başı hükümetle belaya giren Thomas Paine'e, hemen o gün Fransa'ya kaçmasını, yoksa onu yakalayıp ölüm cezasına çarptıracaklarını söylemişti. Paine, Blake'in sözünü dinlemişti. Kaçar kaçmaz da, tutuklama emri çıkmıştı. Bunu da Blake'in siyasal açıdan çevresindekilerden daha akıllı ve daha öngörülü olmasıyla açıklayabiliriz ancak. ${ }^{2}$

Şairlerin yaşamlarındaki kimi ilginç ayrıntılardan beslenerek onların etrafında örülen mitler yazdıkları eserlerin önüne öyle geçer ki artık eleştirmen metnin kendisini değil, şairin kendisini bir edebî olay olarak görmeye başlayabilir. Blake'in eşinin, onun küçükken Tanrı'yı gördüğüne yürekten inanması bunun bir göstergesidir ${ }^{3}$. Şair miti böyle kurulunca onun yazdıkları da olağanüstü bir esin ürünü olacaktır kaçınılmaz olarak. Şair mitinden sanat eseri mitine geçilince de değişen bir şey yoktur aslında. On dokuzuncu yüzyılın sonlarında Romantizmin aşırı veya dekadan biçimi olarak görülen estetikçi görüşün "Sanat, sanat içindir" veya "Bütün sanatlar müziğin durumuna ulaşmak için can atar" gibi fikirleri de toplumun kalanından zihinsel üstünlüğüyle ayrışmış, özel yetenekleri olan sanatçı ve okuru ima etmektedir ${ }^{4}$. Tipkı yazar gibi okura da yüklenen üstün duygusal ve zihinsel yetenekler, bir metni inceleyen okurun duygusal yönü ağır basan izlenimlerini metnin anlamına yeğ tutma veya bu duygusal tepkileri metnin anlamı sayma eğilimini beraberinde getirmiştir ${ }^{5}$. Tarih, arkeoloji ve dilbilimde kök salan tarihselci eleştiri de yazarın yaşadığı dönemin ayrıntılarını bir belgeselci kesinliğiyle ortaya koymayı hedeflemiş; şairin eserleriyle, yaşamındaki belli başlı olaylar arasındaki bağların araştırılmasına

2 Mina Urgan, İngiliz Edebiyatı Tarihi, İstanbul: Yapı Kredi Yayınları, 2008, s. 544.

3 Urgan, İngiliz Edebiyatı Tarihi, s. 543.

4 Buchbinder, Poetry, s. 13.

5 Buchbinder, Poetry, s. 14. 
ağırlık vermiştir. Başka bir ifadeyle, tarihselci eleştiri, edebî eseri, bir tarihsel belgeye dönüştürmüştür ${ }^{6}$. Bu eleştirel yaklaşımlardaki sorun, yazar ve okura yaptıkları vurgu değildir aslında, bu vurguyu yaparken metnin dokusunu ihmal etmeleridir.

Bilindiği üzere, Yeni Eleştiri akımı karşı çıktığı bu üç eleştirel yaklaş1$\mathrm{m} 1$ iki temel hataya indigeyerek alaşağı eder. "Maksat safsatası" (intentional fallacy) ve "hissi safsata" (affective fallacy). Bu kavramlardan ilki, bir eserin anlamın belirleyen ögeyi onu ortaya koyan yazarın maksadında arama uğraşıdır. Bir şiiri anlamak için şairin kendisine yönelmek, onun bu şiiri yazarken neyi hedeflediğini bulmak gerekir. İlk bakışta kulağa anlamlı gelen bu bakış açısının öngöremediği açmazlar vardır. Öncelikle bir yazarın bir eseri yazarken ulaşmak istediği şiirsel etki, anlam sabit değildir. Şair belli bir maksat güdebilir ancak yazım aşamasında fikrini değiştirebilir. Üstelik şair yazım sırasında duygu değişiklikleri de yaşayabilir ki çoğu kez bir şiirin doğuşu bilinç eşiğinin altında ${ }^{7}$, karmaşık ruhsal dönüşümlerin ortasında gerçekleşir. Eğer şair bir şiiri yazarken belli bir maksat gütmüşse, zaten metin bu maksadın gerçekleşmiş bir hâli olduğundan tekrar kaynağa, yani şairin kendisine dönmek gereksizdir. Şairin maksadını anlamak metnin yapısına odaklanarak anlaşılabilir. Eğer şairin maksadıyla şiirin anlamı örtüşmüyorsa, o zaman şair zaten maksadını gerçekleştirememiş demektir ki bu kez de şiirin anlamını şairde aramak anlamsızlaşır. Şiirin en şahsi sanatlardan biri olduğu doğrudur ama lirik şiirde bile konuşan kişi bir dramatik şahsiyettir; şairin kendisi yerine kurgulanmış bir benliktir. Bu nedenle bir şiiri anlamak için yaşam öyküsünün ayrıntılarına odaklanmak gereksizdir; çünkü dramatik şahsiyetin anlattığı ne varsa zaten kullandığı sözcüklerden yola çıkılarak anlaşılabilir; metnin dişına çıkmaya bu yüzden gerek yoktur". Öte taraftan, yazarın metin incelemesinden dışlanmasını savunanların hesaplaşması gereken argümanlar da vardır. Husserl'in fenomenolojisinden etkilendiği bilinen E. D. Hirsch'ün Validity in Interpretation (1967) adlı kitabı, bir eserin anlamının yazarın kastettiğiyle özdeş olduğunu savunur. Hirsch metnin anlamı (meaning) ile imlemi (signification) arasında bir ayrım yapar. Metnin anlamı, 
yazarın niyetine bağlıdır ama imlemleri değişebilir. Eagleton bu durumu şu örnekle açıklar: "Macbeth'i nükleer savaşla bağlantılı olarak yorumlayıp sahneye koyabilecek olmam, bunun, Shakespeare'in kendi bakış açısından Macbeth'in karşılık geldiği 'anlam'dan farklı olduğu gerçeğini değiştirmez”. Kısaca "imlemler tarih boyunca değişir, oysa anlamlar aynı kalır’”10.

Yazarın dışlanması konusunda Yeni Eleştiriciler ve Eco hâlen daha fazla taraftara sahiptir. Yazar metinden dışlanınca anlamın araştırılması bütün ağırlı̆̆ıyla okurun omuzlarına yüklenmiş olur. Okurun, yazarın koyduğu kayıtlardan bağımsız olarak metinle baş başa kalmasının ne sakıncası olabilir? Yeni Eleştiriciler, okurun, metindeki anlam boşluklarını şahsi tecrübeleri ve hisleriyle dolduracakları konusunda tedirgindiler. Yazarın yetkesi bir kez ortadan kalktı̆̆ında, okurun sınırsız özgürlüğü metne ait belli bir anlamın olmadığı fikrini doğuracaktır. Her okur metni istediği gibi yorumlarsa, metne has bir anlamın varlığından da söz edilemez. Böyle olunca metin varoluşunu yitirmekte, okurun hislerine göre değişken anlamlar üretebilen bir makineye dönüşmektedir. "Hissi safsata" kavramının ortaya çıkmasına neden olan endişeler bunlardır ve okurun sınırsız yorum imkânına bir gem vurma amacı taşır. Maksat safsatası nasıl bir şiirin anlamını, o şiirin kaynağıyla karıştırmak anlamına geliyorsa, hissi safsata da bir şiirin anlamını, o şiirin okur üzerindeki ruhsal etkileriyle karıştırmak anlamına gelmektedir ${ }^{11}$. Okur, kendi şahsiyetini bir kenara bırakmadan metne yoğunlaştığında, metnin olası anlamlarıyla, iç dünyasında metnin etkisiyle açığa çıkan anlamları birbirine karıştırabilir. Okur, metni değil, metin aracılığıyla kendi iç dünyasını okuduğunda, metin anlaşılmış değil, kullanılmış olur. Bu sorunu ortadan kaldırmanın yoluysa gayrişahsileşmedir. Nasıl bir şiiri okurken konuşan kişinin şairin kendisi olmadığı konusunda bir uzlaşım varsa, şiiri okuyan kişinin de ampirik okur olmadığ konusunda bir uzlaşım gerekir. Şair, şiirinden kendi şahsiyetini çekerek şiirini evrensel kılar; okur da kendi şahsiyetini metne sokmayarak şiiri evrensel kılmalıdır. Böylelikle metin, yazar ve okurdan yalıtılarak irdelenebilir. Şiirin söz ve anlam sanatları, yapısal özellikleri, ürettiği çağrışım ve imalar, yazarın biyografisinden olduğu kadar, okurun ruh halinden de bağımsız bir şekilde yorumlanır. Böylelikle

9 Terry Eagleton, Edebiyat Kuramı: Giriş, çev. Tuncay Birkan, İstanbul: Ayrıntı Yayınları, 2004, s. 93.

10 Eagleton, Edebiyat Kuramı, s. 93.

11 Wimsatt, "Affective Fallacy", s. 21. 
metin, "ideal okur"una ulaşır122; belli bir kişi değildir bu; ama herkes bir ideal okur olabilir; metnin anlam olanaklarını sorgularken şahsiyetini askıya almayı başarabilen herkesten söz ediyoruz elbette.

Yeni Eleştiricilerin bu görüşlerinin kalıcı olmasında yirminci yüzyılın etkili olmuş dil, sanat ve kültür kuramlarıyla örtüssen yönlerinin bulunması belirleyici olmuştur. Saussure'ün geliştirdiği eşzamanlı dil kuramı, bu kuramın tetiklediği yapısalcı incelemelerde, metinlerin anlamı, esinle kutsanmış dâhi yazarlara değil, yinelenen evrensel örüntüler ve yapılar şeklinde doğrudan dile atfedilmiştir. Tabii yapısalcı kuram ile göstergebilim "kendine yeterli metin" (self-sufficient text) anlayışından uzaktı. Onlara göre metin tek başına ele alınıp irdelenemezdi; çünkü her metin ait olduğu yapının işleyen bir parçasından başka bir şey değildi. Saussure için dil, "nedensiz" (arbitrary), "ilişkisel" (relational) ve "kurucu" (constitutive) bir yapı arz eder. Dil, uzlaşımsal bir yapıdır yani dış dünyayı doğrudan temsil etmez. Dilde seslerin yeri ve anlamı ancak öteki seslerle olan ilişkisiyle belirlenir. "Taş", "kaş”, "yaş" vb. olmadığı için “taş”tır; yani her ses ötekinden bir farkla ayrışır' ${ }^{13}$. Örneğin 8. 25 Geneva-Paris treni maddi bir olguya tekabül etmez. Biz hep aynı trenin geldiğini zannedebiliriz oysa bu saatte gelen trenin lokomotifi, vagonları ve personeli hep farklıdır ${ }^{14}$. Üstelik bu tren 8 . $25^{\prime}$ te de hareket etmeyebilir ama yine de o 8.25 trenidir çünkü tren tarifesinde 8.25 'in anlamı bir işleve dayanır, amaç o treni sadece 7.25 ve 9.25 'ten ayırmaktır. İște bu nedenle dil, dünyayı yansıtmaz onu insan kavrayışına uygun bir şekilde biçimlendirir ${ }^{15}$. Bu kuram yapısalcı bir yönteme dönüştürülüp pratik eleştiriye döküldüğünde, diyelim ki John Donne'ın "Good Morrow" şiiri inceleme konusu olsun, asla şaire değil, şiirin ait olduğu türün yapısal özelliklerine odaklanılır. Donne’ın bu şiiri, "şafak türküsü” olarak çevrilebilecek "alba" adlı lirik bir şiir türüne girmektedir. Gece buluşup gün aydınlandığında kederle birbirlerinden ayrılmak zorunda kalan âşıkları anlatır bu şiirler. Bu yüzden yapısalcı eleştirmen Donne'ın şiirini, "alba” şiir geleneği

12 Buchbinder, Poetry, s. 23.

13 Eagleton, Edebiyat Kurami, s. 126.

14 Ferdinand de Saussure, Course in General Linguistics, trans. Wade Baskin, New York: Philosophical Library, 1959, s. 108.

15 Peter Barry, Beginning Theory: An Introduction to Literary and Cultural Theory, Manchester ve New York: Manchester University Press, 2009, s. 40-43. 
çerçevesine yerleştirir; ayrıca bu şiir geleneğinin ait olduğu kültürel atmosferi, yani "saray aşkı" (courtly love) bağlamını hesaba katmayı da ihmal etmez". Yapısalcı eleştirmenin bu bakış açısı, şiiri metinlerarası bir çerçeveye taşır; nasıl divan şiirinde her bir şiir ortak bir mecaz ağını kullanıyorsa; "alba" şiirinde de öyledir ve araştırılması gereken bu şiirin ait olduğu tür içindeki konumudur. Yeni Eleştiri, yalıtılmış bir metnin titizlikle irdelenmesini önerirken Yapısalc1lar her metni dil içindeki ait olduğu bağlama yerleştirerek irdeler. "Dil" soyut bir kategoridir, "söz" ise dilin somut kullanımıdır; bu nedenle sözün anlamını belirleyen dil içindeki yeri ve işlevidir. Ancak, bu temel ayrıma rağmen, Yeni Eleştiri ile Yapısalcı gelenek arasındaki ortak nokta, edebiyatın ampirik yazarın maksadına indirgenemeyeceğidir.

"Okurun doğumu yazarın ölümü pahasına gerçekleşir" diyor Roland Barthes, "Yazarın Ölümü” başlıklı yazısında ${ }^{17}$. Bu çarpıcı cümlenin okura kazandırdığı özgüven, Yapısalcı okulun Yeni Eleştiri’ nin “hissi safsata” kavramına getirdiği eleştiriden epey uzağa düştüğünü gösterir. Bir özne olarak yazardan kaçarken okura tutulmak anlamına gelebilir bu hamle. Okura tanınan bu imtiyaz, sadece yazarın yetkesini elinden almak anlamını taşımaz, aynı zamanda metne has olası anlamların olmadı $\breve{g}$, anlamın okur tarafından oluşturulduğu imasını da taşır ki bu eğilim metnin de yetkesini elinden almak anlamına gelebilir. Okura mutlak imtiyaz tanındığında metnin aldığı tedirgin edici dönüşümün en açık ifadelerinden birini simgeci şair Paul Valéry'nin şu sözlerinde buluruz:

Anlam'in yorumuna gelince, bu konudaki düşüncelerimi bir çok kez söyledim ama asla yeterli olmuyor. Bir metnin gerçek anlamı yoktur. Yazarın yetkesi diye bir şey yoktur. O ne söylemek isterse istesin, yazdığı şeyi yazmıştır. Bir metin yayımlandıktan sonra herkesin kendi keyfine ve olanaklarına göre kullanabileceği bir alete benzer: Aleti yapan kişinin onu bir başkasından daha iyi kullanacağı kesin değildir. Kaldı ki, ne yapmak istediğini iyi biliyorsa eğer, bu bilgi onun içindeki ne yaptığı algısını allak bullak eder. ${ }^{18}$

Okurun metin üzerindeki hakimiyetinin nasıl bir şey olduğunu rahatlıkla görebiliyoruz bu cümlelerde. Yazarın yetkesinin dışlanması bildik bir durumdur

16 Barry, Theory, s. 38-39.

17 Roland Barthes, "The Death of The Author", Image, Music and Text, Londra: Fontana Press, 1977, s. 148

18 Paul Valéry, "Deniz Gömütlüğü Konusunda”, çev. Orçun Türkkay, Yazarın Kuramı: Eserimi Nasıl Yazdım, haz. İshak Reyna, İstanbul: İletişim Yayınları, 2012, s. 117. 
belki ama Valéry’nin, bir metni, herkesin keyfine ve olanaklarına göre kullanabileceği bir alete benzetmesi, metin-merkezli edebiyat kuramcılarını ürküten şeyin ne olduğunu açıkça gösterir. Metnin anlamı okurun keyfine ve olanaklarına indirgendiğinde metnin içsel bir anlamı olmadığı düşüncesi ağırlık kazanır. Bu görüşün Türk şiirinde de taraftarları vardır. Örneğin Ahmet Haşim, Piyale adlı eseri için yazdığı önsözde şunu söylüyor: "Bir şiirin mânası diğer bir mâna olmağa müsait oldukça, her okuyan ona kendi hayatının mânasını izafe eder"19. Haşim'in, bir şiire mâna verilirken metnin içsel anlamı yerine alıcının, yani okurun rolüne ağırlık vermesi, eleştirmenlerin dikkatini hep çekmiştir; öyle ki Murat Belge, şairin bu yorumuyla "alımlama estetiğii"ne öncülük ettiğini öne sürmüştür ${ }^{20}$. Bu açıdan bakıldığında şu sorulabilir: Okura tanınan aşırı yetke yüzünden sadece yazarın değil, metnin ölümünden de söz etmek olası mıdır? Haklı bir sorudur bu çünkü Valéry'nin kurduğu şu denklem yazarla birlikte metnin de defnedilmesinin önüne geçebileceği şeklinde yorumlanabilir: "Ben bir partisyon yazdım, ama onu ancak ötekinin ruhu ve zihniyle çalındığ1 anda duyabilirim"21. Müzikten ilham alan Valéry orkestral bir eserin bütün enstrümanlarının çalacağı bölümlerin notalara dökülmüş haliyle icra edilen eser arasında farklar olacağından söz etmektedir. Analojiyi kurarsak, bu eser her icra edildiğinde, müzisyenlerin yorumuyla farklı bir anlam, derinlik ve yoğunluk kazanabilir ve hiçbir icra ötekinin aynı olmaz. Farklı bir bakış açısıyla, bu cümle, metnin yetkesini de kurtarabilir çünkü klasik bir eserde partisyon sabit kalır, yorumlar değişir. Hiç değilse sabit kalan bir partisyon vardır, denebilir. Ama modern müzik bu ihtimali de ortadan kaldırır. Modern müzikte partisyon icracıya geniş doğaçlama aralıkları bıraktığı için ortada bestecinin yetkesi diye bir şey kalmaz. İcracı kendisine tanınan doğaçlama alanı ne kadar genişse o denli özgürleşir, böylelikle o eser her icra edildiğinde bambaşka bir tınıya bürünür. O zaman partisyon örneği de Valéry’nin bir metnin gerçek anlamı yoktur cümlesinin bir yankısına dönüşür: Metnin bir özü, yapısı yoktur, o sadece okurun bir oyun alanı, bir olasılıklar uzamıdır.

Okura tanınan sınırsız yetkeden rahatsız olan Umberto Eco'nun $A c ̧ ı k$ Yapıt adlı eserini güdüleyen fikir de aslında budur. 1990 yılında Tanner konferansları için "yorum ve aşırı yorum” konusunu öneren Eco, aşırı yetkilerle do-

19 Ahmet Haşim, "Şiir Hakkında Bazı Mülâhazalar", Ahmet Haşim: Bütün Eserleri, haz. İnci Enginün ve Zeynep Kerman, İstanbul: Dergâh Yayınları, 2013, s. 66.

20 Murat Belge, Şairaneden Şiirsele: Türkiye'de Modern Şiir, İstanbul: İletişim Yayınları, 2018, s. 55

21 Valéry, "Deniz Gömütlüğü Konusunda", s. 117. 
natılmış okurun sınırsız yorum olanaklarına sahip olmasının getirdiği sorunları masaya yatırır. Okura tanınan aşırı imtiyazın sorumlularından biridir aslında Eco, ama iş çığırından çıkınca metnin yapısının okurun aşırı yorumlarına karş1 savunulması gerektiği savını ileri sürmüştür. Şöyle söylüyor:

1962'de ben Opera Aperta'yı (Açık Yapıt) yazdım. Açık Yapıt'ta, estetik değeri olan metinlerin okunmasında yorumcunun etkin rolünü savunuyordum. Kitabı yazdığımda, okurlarım temel olarak işin yalnızca açıklık yönü üzerinde yoğunlaşıp, benim önerdiğim açık uçlu okumanın, yapıtın meydana çıkardığı (ve onu yorumlamaya yönelik) bir etkinlik olduğu gerçeğine gereken önemi vermediler. Bir başka deyişle, ben metinlerin hakları ile yorumcularının hakları arasındaki diyalektiği inceliyordum. Son yirmi otuz yıldır yorumcuların haklarının aşırı öne çıkarıldığı kanısındayım. ${ }^{22}$

Eco'nun Açık Yapıt'ta izlediği yol Valéry'nin ayak izlerini taşır. Yorum metnin okur tarafından icrasından başka bir şey değildir. Özellikle modern eserler yorumcuyu yaratıcılığa sevk eder; onu kendi yorumunu bulması için adeta kışkırtır. Örneğin besteci Henri Pousseur, Scambi adlı parçasıyla ilgili şu açıklamayı yapar: "Scambi, bir müzik parçası olmaktan çok bir olanaklar alanı, seçim yapmaya açık bir davettir" ${ }^{23}$. Müzikten edebiyata geçtiğimizde Stephane Mallarmé'nin yaşamının çeşitli dönemlerinde üzerinde çalıştığı ama asla bitiremediği Le Livre (Kitap) adlı açık yapıtı çıkacaktır karşımıza. Mallarmé için "Dünya bir kitap olmak için vardır" ve şair dünyanın sonsuz olanaklar alanı olduğunu gösterircesine astronomik sayıda kombinasyonlar içeren bir hareketli metin tasarlamışı ır ${ }^{24}$. Ancak bu tür metinlerin bir istisna olduğu da ortadadır. Hareketli metni bir nihai proje olarak tasarlayan Mallarmé'nin uğraşı bile sonuçsuz kaldığına göre, metin ve okur ilişkisini tamamen bu yöne kaydırmak çok da işlevsel olmayabilir. Belki de bu yüzden Eco, okurların abartılmış haklarını sınırlandırmak amacıyla, metinle okur arasındaki ilişkinin rasyonel bir şekilde yeniden temellendirilmesi gerektiğini öne sürer. Nasıl? Şimdi buna bakalım.

Yazarın çoktan unutulmuş hakları bir yana, metnin iç tutarlılığının (tabii eğer böyle bir şey varsa) okurun sınırsız yorumlama ehliyetine karşı savunulmas1, öncelikle eleştirel rasyonalite ile sınırsızlığa izin veren gizemcilik arasındaki

22 Umberto Eco, "Yorum ve Tarih", Yorum ve Aşırı Yorum, çev. Kemal Atakay, İstanbul: Ayrıntı Yayınları, 2016, s. 31. 23 Umberto Eco, Açık Yapıt, çev. Pınar Savaş, İstanbul: Can Yayınları, 2001, s. 8.

24 Eco, Açık Yapıt, s. 22, 23. 
çatışmanın köklerini tartışmayı gerektirebilir. Eco da bunu yapıyor önce. Eleştirel rasyonalitenin Yunan ve Roma düşünce geleneğinin sadece bir yüzü olduğunu hatırlatıyor. Rasyonel gelenek akıl yürütmede bir modus ponens varsayar; yani bir fikir öne sürmek için öncüllere bağlı bir çıkarım yapmamız gerekir. Bu mantık ilkesini Horatius'un dile getirdiği şu etik ilke izler: "Her şeyde öyle bir sınır vardır ki bir şey sınırın bu yanında ve hemen öbür yanında doğru olamaz”. Özdeşlik ilkesi ve çelişmezlik ilkesi, bir şeyin aynı anda hem A hem de B olmasını yadsır; üçüncü halin olanaksızlığı ilkesine göre A ya doğrudur ya da yanlıştır; bir üçüncü olasılık yoktur. Batı rasyonalitesi, işte bu kavramlar üstüne kurulmuştur ${ }^{25}$. Buna karşın Yunan düşüncesinde mistik, sınırsızlığı ve çelişkileri onaylayan bir başka gelenek de vardır. Norma sığmayan, sonsuzluğun büyüsüne kapılmış, çelişki ve tutarsızlık tanımayan bir felsefi görüştür bu. Şöyle diyor Eco:

\begin{abstract}
Yunan uygarlığı, özdeşlik ve çelişmezlik kavramının yanı sıra Hermes'in simgelediği sürekli başkalaşım fikrini geliştirir. Hermes uçucu ve iki anlamlıdır; bütün sanatların atasıdır ama aynı zamanda hırsızların tanrısıdır - aynı anda hem iuvenis (genç) hem senex'tir (yaşl1). Hermes mitinde özdeşlik, çelişmezlik ve üçüncünün olmazlığı ilkelerinin yadsındığını görüyoruz; neden zincirleri de helezonlar halinde kendi üzerine sarılıyor: "Sonra", "önce"den önce geliyor, Tanrı Hermes uzamsal sınır diye bir şey tanımıyor ve aynı anda farklı k1lıklarda farklı yerlerde olabiliyor. ${ }^{26}$
\end{abstract}

Gizemci görüş evrenin sırlarının akıl ve mantıkla, anlaşılır sözcüklerle kavranamayacağını, evrende her anlamın bir başka anlamı ima eden bir aynalı oda gibi olduğunu varsayar. Yunan gizemciliğinden Yeni Platoncu hıristiyan teolojisine evrilen bu dünya görüşü çelişki tanımaz çünkü bu görüşe göre ilk bakışta çelişkili gibi görülen her şey aslında başka bir şeyi ima ettiği için hakikatle örtük bir şekilde tutarlıdır. Ancak bu denli karmaşık bir yorum silsilesiyle makul bir düzlemde buluşmak olanaksızdır ve bu yüzden özdeşlik ilkesi çöker. Her şey bir başka anlama geldiğinden neyin hangi anlama geldiği takip edilemez, bu yüzden de yorumun belirsizliği bir anlamda kutsanır. Bir şey ne kadar müphemse o kadar derin anlamlı zannedilir. Yorumun sınırsızlığında kutsallık görmenin bir totolojiye yaslanması da bu yüzdendir:

25 Eco, "Yorum ve Tarih", s. 35-36.

26 Eco, "Yorum ve Tarih", s. 38. 
Her ne zaman bir giz keşfedilirse, bu giz bir başka gizi imleyecek ve bu, aşamalı bir hareket içinde nihai gize doğru ilerleyecektir. Gene de, nihai giz diye bir şey yoktur. Hermetik bilgiye ermiş olmanın nihai gizi, her şeyin bir giz olduğunu bilmektir. Dolayısıyla, hermetik giz boş bir giz olmalıdır çünkü herhangi bir gizi açığa çıkardığı iddiasında bulunan kişi, hermetik gize ermemiş ve kozmik gizem bilgisinin yüzeysel bir düzeyinde durmuş demektir. Hermetik düşünce bütün dünya sahnesini bir dil olgusuna dönüştürür; aynı zamanda da dilin her tür iletişim gücünü elinden alır. ${ }^{27}$

Dilin iletişim işlevinin bu metafizik görüşle birlikte kasten zayıflatılması lirik şiiri besleyen ögelerden biri olmuştur. Şiirin vecd halinde söylenen bir tür dua gibi algılanmas1 ${ }^{28}$, anlamın hep ötelenmesini beraberinde getirir. Evren hakkında belli açıklamalar getiren bir mistik söz olmak yerine lirik şiir, okurda ruhsal coşkuyu diri tutan bir ayin havasına bürünür. İşte bu nedenle lirik şiirde herhangi bir anlam aramanın beyhude olduğu, sözlerin müzikal tınısından, yarattığı ritüalistik etkiden pay almanın gerekli olduğunun altı hep çizilir. Bu gizemci, ruhsal esrimeye dönük düşüncenin çizdiği hattı şöyle tanımlıyor Eco: "Yani hermetik irrasyonalizm bir yandan mistiklerle simyacılar; öte yandan da Goethe'den Gerard de Nerval'e ve Yeats'e, Schelling'den Franz von Baader'e, Heidegger'den Jung'a şairlerle filozoflar arasında gidip gelir"29. Valéry'nin "Bir metnin kesin bir anlamı yoktur" düşüncesi de bu hermetik geleneğin bir uzant1sıdır; hatta, postmodern kuramın yaygınlaştırdığı "sürekli anlam kayması" düşüncesinde de hermetik gizemciliğin yankısını işitmek zor değildir ${ }^{30}$.

Öyle anlaşılıyor ki Eco, okurların, arka planında gizemcilik olan sınırsız anlamlandırma çölünde kaybolup gitmesini önlemek, bir çöl fırtınasında kum taneleri gibi savrulan anlamların belli bir eleştirel akıl süzgecinden geçirilmesini istemektedir. Bu yüzden Eco, okura sınırsız anlam üretme olanağı veren "okurun maksadı" (intentio lectoris) kavramı yerine, metnin iç tutarlılı̆̆ını koruma altına almamızı telkin eden "metnin maksadı" (intentio operis) kavramını önerir. Eco’ya göre bir “metin, örnek okurunu üretmek amacıyla tasarımlanmış bir aygıttır"31. İtinayla kurulmuş bu cümlenin amacı okurun bir metni yorumlarken

27 Eco, "Yorum ve Tarih", s. 41.

28 Orhan Okay, Poetika Dersleri, Ankara: Hece Yayınları, 2005, s. 134.

29 Eco, "Yorum ve Tarih", s. 43.

30 Eco, "Yorum ve Tarih", s. 43.

31 Eco, "Metinleri Aşırı Yorumlama", s. 72. 
başına buyruk bir hazcı gibi davranmasının önüne geçmektir. Tabii bu cümlede ampirik yazarın yetkesi de yankılanmakta, genellikle metinle okur arasında geçen yorum tartışması, yazarı da mezarında uyandırmaktadır. Eğer bir metin örnek okurunu inşa etmek için tasarlanmışsa ampirik okur bu tasarının mimarıdır. Ancak Eco'nun amacı elbette İsa rolüne soyunup Roland Barthes'ın çoktan defnettiği yazar Lazarus'u diriltmek değildir. Onun söz ettiği yazar, ampirik yazar değil, metnin iç tutarlılığıyla örtüşen, örnek okurun zihninde canlandırdığg bir yazardır. Zaten Eco'nun öne sürdüğü fikir ampirik yazarla kurmaca yazar arasındaki farkları tartışmamızı gerektirmeyecek ölçüde açıktır aslında. Önerdiği şey kısaca şudur: Bir metni yorumlarken rasyonel davranmak, eserin iç tutarlılığına uygun bağlantılar kurmak ve daha basit çözümler ortada dururken karmaşık ve mantığa aykırı anlam arayışlarına girmemek. Şöyle söylüyor Eco:

Intentio operis'le ilgili bir tahmin nasıl kantlanabilir? Bunun tek yolu, söz konusu tahmini tutarlı bir bütün olarak metin üzerinde sınamaktır. Bu da eski bir fikirdir ve Aziz Augustinus'tan kaynaklanmaktadır (De doctrina christia$n a)$ : Bir metnin belli bir bölümünün belirli herhangi bir yorumu ancak metnin başka bir bölümünde doğrulandığında kabul edilebilir; metnin bir başka bölümünce çürütüldüğünde ise reddedilmelidir. Bu anlamda metnin içsel tutarlıl1ğ1, okurun başka türlü denetlenmesi imkânsız itkilerini denetler. ${ }^{32}$

Eco'nun aşırı yorum olarak gördüğü şey kuramsal açıdan nettir ama iş uygulamaya gelince bu yaklaşımına getirilebilecek haklı eleştiriler de vardır. Bir metnin iç tutarlılı̆̆ kavramı örneğin Richard Rorty’nin kabul edilemez bulduğu bir mecazdır. Ona göre bir metnin tutarlılığı diye bir şey yoktur. Çünkü metnin anlamsal bağlamı okur tarafından üretilir. Tutarlılık bir metnin betimlenmeden önce sahip olduğu bir şey değildir; biz birleştirmeden önce noktaların tutarlılığının olmaması gibi ${ }^{33}$. Yine de Eco'nun aşırı yorum için verdiği şu örnek ikna edicidir: Bir metinde "Gül mavidir" cümlesinin belirip belirmediğine karar vermemiz için bu cümlenin tamamını metinde aramamız gerekir. Birinci sayfada "gül” sözcüğünü, ellinci sayfada da "mavi gergedan" sözcüğünü bulmuşsak hiçbir şey kanıtlamış olmayız ${ }^{34}$. Bir metinde sınırlı sayıda ses ve

32 Eco, "Metinleri Așırı Yorumlama", s. 73.

33 Richard Rorty, "Pragmatistin Yolculuğu", s. 107.

34 Eco, "Metinleri Aşırı Yorumlama", s. 64. 
sözcük kullandığımız için, eğer bağlamsal bir çerçevemiz yoksa, istediğimiz her ifadeyi bu şekilde bulabiliriz. Tıpkı Rossetti'nin, Dante'nin uçsuz bucaksız eserinde, zorlaya zorlaya bir Gül-Haç simgeciliği arayıp başarısız olmasında olduğu gibi: “ 'Rosa' (gül) İlahi Komedya' da sekiz kez tekil, üç kez çoğul olarak geçer. 'Croce' (haç) on yedi kez belirir. Ancak bu iki sözcük asla bir arada belirmezler" ${ }^{35}$. Tartışmada aşırı yorumun savunusunu yapan Jonathan Culler'ın da uygun bulmadığı bir yorumdur bu. Ona göre Rossetti, metinde var olmayan bir izleğin peşine düşmüş ve bu nedenle ikna edici olmayan yetersiz bir yorum yapmıştır $^{36}$. Öyle anlaşılıyor ki Culler aşırı yorumla yetersiz yorum arasında bir ayırım yapmakta, Rossetti örneğini bir aşırı yorum olarak değerlendirmenin doğru olmadığını vurgulamaktadır. Rossetti’nin Dante çözümlemesi, Eco’ya göre aşırı, Culler'a göreyse yetersiz bir yorumdur.

Eco'nun aşırı yorum üzerine yürüttüğü tartışmanın can alıcı noktası ise, Geoffrey Hartman'ın, Wordsworth'ün “Lucy” adlı şiiri üzerine yaptığı çözümlemeyle ilgilidir. Bu çözümlemeyi Eco, fazla cömert bulmaktadır. Ona göre, Yale yapıçözücülerinin önde gelen eleştirmenlerinden Hartman'ın bu şiirle ilgili yorumunun doğruluğunu sınamak zordur. Hartman akıl dışı bir şey öne sürmez ama iddiaları Eco'nun yorum normlarının ötesine geçmiştir. Bu açıdan Eco, her ne kadar Hartman'ın yorumunu büyüleyici bulsa da onu eleştirmekten kaçınmaz. Hartman'ın çözümlemesi şu açıdan Eco'nun yorum ölçütlerini aşmaktadır: Metinde var olan (in praesentia) bazı sözcüklerin, var olmayan (in absentia) bazı sözcükleri ima ettiğini iddia ederken neden-sonuç zincirini doğru kullanamamak, hatta bu çıkarsamayı yaparken keyfi davranıyor izlenimi vermek. Hartman, "Lucy” şiirinin şu bölümünü inceler:

35 Eco, "Metinleri Aşırı Yorumlama", s. 65.

36 Jonathan Culler, "Aşırı Yorumun Savunusu", s. 123. 
A slumber did my spirit seal;

I had no human fears:

She seemed a thing that could not feel

The touch of earthly years.

No motion has she now, no force

She neither hears or sees,

Rolled round in earth's diurnal course

With rocks and stones and trees.

(Sakin bir uyku mühürledi ruhumu;

İnsanca korkularım yoktu:

Yeryüzü yıllarının dokunuşunu

Hissedemeyen bir şey gibiydi o.

Hareketsiz artık, güçsüz;

Ne duyar, ne görür,

Dönüp durur yeryüzünün günlük seyrinde

Kayalarla, taşlarla, ağaçlarla.) $)^{37}$

Hartman'ın yorumu şiirde eğik olarak verilen sözcüklerin çağrıştırdığ yakın sesli ve yakın anlamlı sözcüklerin keşfine dayanır. Bu keşif sayesinde şiirin ölüm izleğinin anlam ufku genişler. Şairin bilinçdışı, metinde var olmayan bu sözcüklerin metne çağrışım yoluyla sızmasını mı sağlamıştır? Bunu bilemeyiz ancak metinde var olan sözcüklerin yankısı okur tarafından işitilebilir ve metne dahil edilebilir. Bu tipik bir metin merkezli yorumdur ama Eco, bu yorumda norm dışı bir uygulama görmektedir. Hartman'ın bu çarpıcı yorumu şöyledir:

Bazı başka eleştirmenler Wordsworth'ün dilinin uygunsuz bilinçdışı söz oyunları içerdiğini bile göstermektedirler. Böylece 7. dizedeki diurnal (günlük) sözcüğü, die (ölmek) ve urn (ölü küllerinin saklandığı kap) sözcüklerine ayrılır; course (seyir) ise, corpse (ceset)'in eski sesletimini anımsatabilir. Gene de, bu yoğunlaştırmalar, açıklayıcı olmaktan çok, yorumu güçleştirmektedir; ikinci kıtanın gücü temel olarak grave (mezar) sözcügünün yerine örtmeceli olarak bir yerçekimi imgesinin geçirilmesinden kaynaklanmaktadır (Rolled round in earth's diurnal course; Dönüp durur yeryüzünün günlük seyrinde). Ve bu kıtanın tonu konusunda görüş birliği bulunmamasına karşın, 
şurası açık ki, yazıya geçirilmemiş olmakla birlikte zihinde oluşturulan bir sözcük dile getirilmektedir. Fears (korkular), years (yıllar) ve hears (duyar) ile uyaklı bir sözcüktür bu ancak şiirin son hecesince dışta bırakılmıştır: Trees (ağaçlar). Bunu tears (gözyaşları) olarak okuduğumuzda, yaşam verici, kozmik eğretileme yaşam kazanır, pastoral elejide olduğu gibi şairin yakınması doğada yankılanır. Bununla birlikte tears (gözyaşları) yerini, yazılı olana b1rakmak zorundadır, yavan ancak kesin bir sese, anagramı trees (ağaçlar)'a. ${ }^{38}$

Öyle anlaş1lyyor ki Hartman'ın yorumu, Eco'nun yorum için geçerlilik ölçütünün temelini oluşturan rasyonellik ilkesini zorlamaktadır. Gizli anlam katmanları bulmak için metinde var olmayan sözcükleri üretmek, birbirinin anagramı olmayan sözcükleri sanki öyleymiş gibi yorumlamak... Kötümser bir bakış açısıyla yaklaştığımızda, gerçekten de Hartman'ın çözümlemesi bu türden kusurları barındırır. Gerçi Eco, metinde var olan sözcüklerin var olmayan sözcükleri çağrıştırabileceğini belirtir (die, urn, corpse ve tears sözcüklerinin, diurnal, course, fears ve hears sözcüklerinden çıkarsanması). Ancak grave (mezar) sözcüğünü çağrıştıran, metinde var olmayan, okurun yoruma dayalı kararıyla üretilen gravitation (yerçekimi) imgesidir. Üstelik Hartman hatalı bir şekilde tears sözcüğünün trees' in anagramı olduğunu iddia etmiştir ${ }^{39}$. Bununla birlikte, Eco'nun da belirttiği üzere, Hartman'ın yorumu metnin öteki ögeleriyle çelişmez; bu yorumun çok cömert olduğu söylenebilir belki ama iktisadi açıdan saçma bir yorum değildir bu: Eco bu tartışmayı, "Kanıt zayıf olabilir ancak metne uymaktadır"40 diye sonlandırır. Eco'nun bu yorumu zoraki de olsa kabullenişi, yeniliğe açık, metinlerden haz duymak isteyen okurları bir nebze rahatlatır. Çünkü Hartman'ın yorumu anlam ufkumuzu metinden koparmaks1zın öylesine genişletir ki gerçekten de bir kızın ölümünden duyulan keder birdenbire yaşamın kozmik anlamını bize yeniden sorgulatır. Şiirin yüzeyinde var olmayan sözcükler var olan sözcüklerin bir uzantısı, bir yankısı gibi kendini yüzeye vurup anlamı derinleştirir. Şairin bilinçdışı tıpkı bir rüya işleminde (dream work) olduğu gibi pek çok yakın sesli ve yakın anlamlı sözcüğü metindeki belli başlı sözcükler üzerinde yoğunlaştırmış olabilir. Böylelikle buzdağının görünen

38 Eco, "Metinleri Aşırı Yorumlama”, s. 69. Hartman'ın çözümlemesi için bk. Geoffrey H. Hartman, Easy Pieces, New York: Columbia University Press, 1985, s. 149-150.

39 Eco, "Metinleri Aşırı Yorumlama", s. 69.

40 Eco, "Metinleri Aşırı Yorumlama", s. 70. 
ve görünmeyen kısımları bir araya getirilebilir ve ölümle ilgili birbirini tamamlayan sözcükler ortaya çıkarılıp bütünleşik bir anlama varılabilir.

Culler'ın, Eco’ya verdiği yanıt, normdışı yorumun nasıl olması gerektiğine dair bir manifesto niteliği taşınmaktadır. Ona göre Hartman'ın yorumu aşırı olmak bir yana, oldukça geleneksel bir yöntemin sonucudur. Culler, yazınsal duyarlılık olarak bilinen, bir dizede başka dizelerin, sözcüklerin ya da imgelerin yankılarını duymak olarak tanımladığı bir yöntemi sergilediğini belirtiyor Hartman'ın. Culler'a göre Hartman, Wordsworth'ün yalın söyleyişinin ardında, potansiyel söz oyunları, çağrışım ve imaları bulurken oldukça rasyonel bir yorum geliştirmiştir. Culler şöyle devam ediyor:

Bu yumuşak, ölçülü yorum pasajı ancak Hartman güçlü iddialarda bulunsa bir aşırı yorum niteliği kazanabilirdi — sözgelimi, ağaçların, kayalar, taşlar ve gözyaşları gibi yuvarlanmadığı gerekçesiyle trees'in (ağaçlar) şiirin son dizesine ait olmadiğ iddiası (Rolled round in earth's diurnal course / With rocks and stones and trees; Dönüp durur yeryüzünün günlük seyrinde / Taşlarla, kayalarla, ağaçlarla). Ayrıca Hartman, daha önceki bir dizenin (She neither hears nor sees; Ne duyar, ne görür) daha doğal sırasının She neither sees nor hears olduğunu, bunun da bitiş uyak sözü olan trees yerine tears gibi bir sözü gerekli kıldığını öne sürebilirdi. Dolayısıyla, iyi bir "giz yandaşı" olarak şu sonuca varabilirdi: Bu küçük şiirin gizli anlamı, gerçekten de tears'ın bastırılması olup onun yerine trees geçirilmiştir (ağaçlardan ormanı görememek). Bu, aşırı yorum olurdu ancak aynı zamanda Hartman'ın gerçekte yazdığından daha ilginç ve şiiri aydınlatıcı olurdu (sonuçta bu yorumu reddetsek bile); Hartman'ın yazdığı, dediğim gibi, şiirin dili ardında gizlenen "imalar”ı belirlemek üzere yapılmış hayranlık uyandırıcı bir geleneksel edebiyat duyarlılığı alıştırması izlenimini veriyor. ${ }^{41}$

Culler'ın yaptığı yorum metin tarafından destekleniyor mu? Her ne kadar bu yorum metinle bir bağ kursa da temelleri metnin maksadından ziyade okurun spekülasyon gücü tarafından atılmıştır. Şiir sanki gizli bir el tarafından söylemek istedikleri engellenmiş bir metindir ona göre. Sanki bazı dizelere, kurulması gerektiği gibi kurulamaması için bir müdahale edilmiştir; ağaçların şiire yabancılığı böyle bir müdahaleyi ele verir; çünkü kayalar ve taşlar, gözyaşları gibi yuvarlanabilir ama ağaçlar toprağa çakılı durmak zorundadır. Şiirin 
organik bütünlüğünü bozan bu keşif neden daha fazlasını söylemesin ki okura? Yorumcu bu uyumsuzluğun izini sürerken şunu da fark eder: Kulağa uygunluk açısından She neither sees nor hears olması gereken dize, She neither hears nor sees olarak yazılmış ve bu yüzden uyak tears olması gerekirken olamamış da trees olmuştur; işte bu nedenle okur, "ağaçlardan ormanı göremez". Doğallıkla, aşırı olarak adlandırılması daha kolaydır bu yorumun. Çünkü bu yorumu okurken şiirin anlam örgüsünden kaçıp başka bir anlam örgüsü kurmaya çalışan bir okurun bilinçli çabasını fark ederiz. Zaten Culler'ın önermek istediği yöntemin ağırlık noktası da burasıdır. Her zaman mükemmel sonuç vermeyebilir belki ama okurun metnin bağlamına bağlı kalmadan bir başka bağlam oluşturmasının önemine dikkat çeker Culler. Bunu yaparken de Wayne C. Booth'un "yorum" ile "aşırı yorum" karşıtllğı yerine önerdiği "anlama" ile "aşırı anlama" karşıtlığını kullanır. Booth’un, "anlama”yı, Eco'nun metne bağlı yorum pratiği olarak değerlendirdiğini söylüyor Culler. Yani, metnin 1srar ettiği soruları sormak ve yanıtları bulmaktır anlamak. Örneğin, "Bir zamanlar üç küçük domuzcuk varmış" sözünü alalım. Bu cümle okurdan, "Neden üç?” veya "Somut tarihsel bağlam nedir?" gibi soruları talep etmez; talep ettiği soru genellikle, "Peki ne olmuş?" sorusudur. Oysa "aşırı anlama”, metnin örnek okuruna sormadığı soruların ardından gitmektir ${ }^{42}$. Başka bir ifadeyle, okurun gündemi, metnin gündeminden farklı olabilir ve okur kendi sorularının ardından gidebilir. Öyle ki metnin teşvik etmediği soruların ardından gitmek, çoğu zaman alışkanlık kırıcı etkisi yaparak metnin anlam ufkunu genişletir. Culler, Booth'un aşırı anlamanın izlediği yolu göstermek için Booth'un metne sorular sorduğu şu alıntıyı yapar:

Sen, görünüşte masum, üç domuz ile kötü kurt masalı, senin seni koruyan ve
sana tepki veren kültür hakkında söyleyecek neyin var? Seni yaratan yazarın ya
da halkın bilinçdışı rüyaları hakkında? Anlatısal askıdalığın tarihi hakkında?
Açık ve koyu tenli ırkların ilişkileri hakkında? İriyarı ve ufak tefek, saçlı ve kel,
zayıf ve şişman insanlar hakkında? İnsan tarihindeki üçlü örüntüler hakkında?
Teslis hakkında? Tembellik ve çalışkanlık, aile yapısı, ev mimarisi, perhiz uy-
gulaması, adalet ve öç alma standartları hakkında? Duygudaşlık yaratmak üzere
anlatısal bakış açısının manipülasyonlarının tarihi hakkında? Geceler boyunca
bir çocuğun seni okuması ya da ona seni anlatmaları iyi bir şey midir? İdeal
sosyalist devleti kurduğumuzda, senin gibi öykülere izin verilecek mi, verilmeli

42 Culler, “Aşırı Yorumun Savunusu”, s. 125. 
mi? Şu bacanın ya da cinsiyetten hiç söz edilmeyen bu ödünsüz erkek dünyasının cinsel imaları nelerdir? Bütün o oflama puflama nedir? ${ }^{43}$

$\mathrm{Bu}$ sorular masalın okura geleneksel olarak vermek istediği kıssadan hissenin ötesine geçer; bu masalın kanıksanmış işlevinin ne olduğunu tartışmaya açar. Bir anlamda Booth'un aşırı anlama uğraşı bir toplumun basmakalıp iletilerle şekillendirilmeye çalışılmasına getirilen bir başkaldırı olarak da görülebilir. Çünkü metinler, masal olsalar bile, asla masum şeyler değildir. Tam tersine, edebî eserler, yaydıkları ideolojik örüntüyü örtbas etmeye yarayan tekniklerle dolu birer siyasal aygıttır aynı zamanda. Masallar genellikle iyiler ve kötülerin mücadelesini anlatırken sık sık bazı canlıları ötekileştirir; zihinlere işlenen bu tür şablonlar onaylanan ve onaylanmayan karakterler arasında kesin bir ayırım yapar. Booth, iyi ve kötünün, çalışkan ve tembelin, güzel ve çirkinin bu denli kesin çizgilerle ayrıştırılmasında bir eğitim kusuru görmektedir. Ayrıca masallarda seçilen sayıların, şekil ve nesnelerin de masum olmadığını, simgelerle işleyen bir standart düzenin çocukların zihinlerine erken yaştan itibaren kazındığını ima etmekte ve bunda bir fayda olup olmadığını sorgulamaktadır. Kuşkusuz, Booth'un bu endişeleri kısacık bir masalın okurdan beklediği anlama ve yorumlama performansını fazlasıyla aşar. Bir anlamda Booth, eleştirel bir okuma yapmakta, metni, beklenmedik sorularla yargılamaktadır. Eğer aşırı anlama (veya yorumlama) buysa, demokratik kültürü gelişkin açık bir toplumda, çocukların zihinsel gelişiminin bir parçası olan masallara yönelik böyle bir sorgulamaya kim itiraz edebilir?

Yazarın yetkesinin elinden alınması veya okurun yorum kapasitesinin sınırlandırılması bir metnin anlaşılmasını kolaylaştırır mı zorlaştırır mı? Bu soruya somut örneklerden yola çıkmadan yanıt vermek olanaksız. Eco'nun açtığı tartışmayı eleştirel bir gözle incelediğimizde, üzerinde yorum yapılan örneklerin bazılarında en kolay bertaraf edilebilir taraf gibi görünen yazarın bile yorumlama ediminden sanıldığı kadar kolay dışlanamayacağını görürüz. Yazar gönül rahatlığıyla dışlanamaz çünkü ona ait dilsel ve kültürel bağlam metne sızmıştır veya yazarın kullandığı_ “"açık yapıt” örneğinde olduğu gibi-bazı avangart teknikler onu da yorum sırasında işin içine katmamızı gerektirebilir. 
Öte taraftan bir metnin anlamını veya olası anlamlarını kuvveden fiile çıkaran özne, okurdur. Buradaki tartışma şudur: Okur ya metne içkin olduğu varsayılan anlam, ima ve çağrışımları keşfeder ya da metinle etkileşime girip sınırsız yaratıcı gücüyle anlam, ima ve çağrışımlar icat eder. Eco'nun Rorty ve Culler'la girdiği tartışmanın ana ekseni, okurun bir kâşif mi yoksa bir mucit mi olması gerektiği sorusunda düğümlenir. Her ne kadar bu fikirlerin her birinde belli bir doğruluk payı olsa da, yazar, okur ve metne odaklanarak yapılacak çözümlemeler, bu spekülasyonların ete kemiğe bürünmesini ve okura daha aydınlatıcı bir tecrübe yaşatmasını sağlayabilir. Şimdi üç şiirden yola çıkarak, sırasıyla, yazarın, metnin ve okurun hangi koşullarda yorumun ağılık merkezi hâline geldiğini göstermeye çalışacağız.

\section{Şairin Hayatı Şiire Dahil}

Şiir en şahsi sanatlardan biri olagelmiştir. Şairlerin sık sık "ben” zamirini kullanırlar ve okur bunu çoğu kez şairin kendisi olarak algılar. Kuşkusuz şiirde "ben" her zaman şairin kendisine bir gönderme yapmaz. Aksine, okurun o "ben"i herkes, hatta kendisi olarak düşünmesi ve böylelikle anlatımın evrenselleşmesi beklenir. Şair "ben” dediğinde, doğrudan kendisinden söz ediyor olabilir ama daha çok şair, her şiirinde birbirinden farklı kurmaca kimlikler oluşturur. Şiir, o şairin yaşadığı somut bir tecrübeyi dile getirse bile, dil sanatının baskısı, şairi günlük yaşamdan alıp şiirin bağlamına atar. Şiirsel roller, jest ve söyleyişler, şiirin uzun tarihinden süzülüp gelir. Bir anlamda şair bir maske takıp kendi kimliğinden sıyrılır; şiirsel bir kimliğe bürünür. Bu o kadar kritik bir zihinsel işlemdir ki şiirin bir iç dökme veya dertleşme sanatı olarak yerleşmesinin önüne geçer. Şairin şahsiyeti en fazla lirik şiirde ortaya serildiğinden modern lirik şairler eserlerindeki yoğun biçimsel deneylerinin ampirik yaşamın tekdüze potasına indirgenmemesi için kendi şahsiyetlerinden kaçınmaya çabalamışlardır. Başka bir ifadeyle, şahsiyetten kurmaca şahsiyete veya gayrişahsileşmeye doğru bir evrim geçirmiştir lirik şiir. Cemal Süreya bu çarpıcı dönüşümü fark eden şairlerden biridir. "Şairin Hayatı Şiire Dahil” başlıklı yazısında Süreya, şiirlerinde kendi adlarını geçiren şairlere eskiden daha sık rastlandığını söyledikten sonra sözlerine şöyle devam eder: 
Orhan Veli, Cahit Sıtkı, Ziya Osman böyleydi. Cahit Külebi ne çok severdi adını! İlhan Berk de ayrı bir şiir kaynağı gibi görürdü kendininkini. Hele bir dönemde kimlik cüzdanındaki bilgileri olduğu gibi şiire aktarmak bir içtenlik belirtisi sayılırdı. Ümit Yaşar gibi şiirinde kendine yergiler yağdıranlar da vardı. Melih Cevdet'in bir grup fotoğrafını anlatan şiirine, S. Aldanır aynı fotoğraftan çıkış yaparak yine şiirle karşılık vermişti. Şair, kendinden, kendi küçük çevresinden, daha çok oradan bakıyordu dünyaya. Türkân'dı, Sevim'di, Güler'di, Güzin'di (Salah Birsel'inki). 'Son yolcunun adı Attila İlhan'dı'. ${ }^{44}$

Süreya şiirin bir zamanla maskesiz yazıldığını mı ima ediyor? Olabilir ama öyle olsa bile şairin yaşamından damıttığg bir kesit şiire dönüştüğünde okurun zihninde evrensel bir gerçekliği uyandırabilir. Tabii tam tersi de olasıdır. Şairin hayatından yola çıkarak sunduğu kesit evrensel bir değer kazanabilir belki ama genellikle okurun dikkati böyle eserlerde şahsiyet üstünde yoğunlaşacaktır. Nâzım Hikmet'in şiirlerini zaman zaman biyografiye yaslanması, şiirleriyle polemiklere girmesi, kimi şiirlerinde sevdiği kadın adlarına yer vermesi devrimci romantizmin bir gereğidir muhtemelen ve bu haliyle de bu şiirler evrensel bir amacı yüklenebilir. Ama buna rağmen bu şiirleri okuyan bir okurun meraklı bakışlarının Nâzım’ın şahsiyeti üstünde fazlaca yoğunlaşmasının önüne geçmek de kolay değildir. Nâzım hakkında yazılan en önemli kitaplardan ikisinin adı bile onun şiiriyle hayatı arasındaki bağ 1 gözler önüne serebilir ${ }^{45}$. Öte taraftan bir şair hayatını şiirinden kaçırmış olsa bile okurun ilgisi hınzırca bu yönde takılı kalabilir: Süreya'nın, "Şiir okuru, şairin, yapıtına yansımamış hayat bölümünü de o yapıtın bir parçası sayıyor" ${ }^{46}$ sözleri, okurların eğilimlerini derinlemesine kavramış bir şairin tecrübesini yansıtmaktadır. Şairin hayatıyla şiiri arasında bağlar kuran çalışmalar bu nedenle ilgi çeker ve keyifle okunur. Tabii bu eserlerin salt bir öz yaşam merakından kaynaklandığını söylemek de eksik bir yaklaşım olur. Çünkü bir sanatçının entelektüel gelişimini sağlayan çevre ve koşulları araştırmak, o şairin eserlerindeki kimi ayrıntıları anlamayı kolaylaştırabilir. Ancak yazarın hayatı çoğu kez onunla kurduğumuz özdeşlik yüzünden hedeften sapmamıza neden olur. Yazarın yetkesine duyulan güven-

44 Cemal Süreya, "Şairin Hayatı Şiire Dahil”, Folklor Şiire Düşman, İstanbul: Can Yayınları, 1992, s. 61.

45 Saime Göksu, Edward Timms, Romantik Komünist: Nâzım Hikmet'in Yaşamı ve Eseri, çev. Barış Gümüşbaş, İstanbul: Doğan Kitap, 1999. Memet Fuat, Nâzım Hikmet: Yaşamı, Ruhsal Yapısı, Davaları, Tartışmaları, Dünya Görüşü, Şiirinin Gelişmeleri, İstanbul: Adam Yayınları, 2006.

46 Süreya, "Şairin Hayatı Şiire Dahil”, s. 62. 
sizlik esasında romantikleştirilmiş yazar miti yüzünden metnin gitgide üstünün örtülmesinden kaynaklanır. Nitekim Cemal Süreya da bunun farkında olmalı ki Rüştü Onur ve Muzaffer Tayyip Uslu gibi genç yaşta hastalanıp ölmüş (edebî olarak şehit düşmüş) şairlerin ortaya önemli eserler koymadıkları halde kazandıkları şöhreti eleştirir: "İki güzel şiirleri var. Onlar da kendi yaşıılları olan bugünkü büyük ustaların yazdıklarının yanında bir şey değil. Yine de, açın seçkileri, hep rastlarsınız onlara" ${ }^{47}$ diyor Süreya, haklı olarak. Hatta Süreya daha da ileri gidip edebî şehit mitolojisi yüzünden seçkilerin nesnelliğini yitirdiğini de ekler ve şu öneride bulunur: "Yeni bir seçki öneriyorum"48.

İnsan zihni bir şeyi mitleştirip bir başka şeyi kolaylıkla ötekileştirebiliyor. Nasıl romantik deha figürü bir mitse, yazarın ölümü de bir başka mittir. Svetlana Boym'un Tırnak İçinde Ölüm: Modern Şairle İlgili Kültürel Mitler adlı eserinde mücadele edip aşmaya çalıştı̆̆ mit, Yeni Eleştiri ve Yapısalcı ekollerin yazarın öldüğü fikrini âdeta dinsel bir ayin gibi tekrar edip durmalarıdır. Oysa yazar mezara kondukça kalkıp geri gelmekte, dolambaçlı yollardan kendisini metinde görünür k1lmaktadır. Mallarmé gibi şairlerin kendi eserlerinden kendi biyografik varlıklarını sürekli silme çabası da esasında öznenin metin içindeki müdahaleci varlığını bir başka yoldan teyit eder. Bu açıdan bakıldı ğında şair, ister görünmez olmak isterse görünür olmak istesin, bütün bunları kurgulayan el, kendisinin elidir; bu el, şairin suretini gizleyebilir veya aşikâr kılabilir ama her şekilde bir metne vücut veren özneyi yok etmek imkânsızdır. Boym'un “ 'yaşam', 'metin' ve 'kültür'ü, aralarında bir öncelik sonralık ilişkisi kurmadan, bir arada okumaya yönelik alternatif stratejiler geliştirmeye çalışıyorum"49 sözüyle başladığı kitabı, günümüz eleştirisini yazarın ölümü mitinden kurtaran önemli bir girişimdir bu yüzden. Deha şair veya ölü şair mitlerinin edebiyat eleştirisini hadımlaştırıcı etkilerinden arındırma çabasına girişen Boym'un kitabının son bölümünde söyledikleri yaşamdan ürküp kaçmadan da edebiyat çözümlemesi yapılabileceğini göstermektedir:

Mallarmé'nin intihara götüren tahrifi yaşamda intihardan sakınma amaçlı önleyici bir tür terapi olarak yazıda nasıl ortaya çıktığını gözlemledik. Mallarmé

47 Süreya, "Şairin Hayatı Şiire Dahil", s. 63.

48 Süreya, "Şairin Hayatı Şiire Dahil", s. 64.

49 Svetlana Boym, Tırnak İçinde Ölüm: Modern Şairle İlgili Kültürel Mitler, çev. Emine Ayhan, İstanbul: Metis Yayınları, 2010, s. 9. 
yine benzer biçimde paradoksal bir tarzda metin ile yaşam arasındaki metonimik ilişkiyi vurguluyor, aynı zamanda da yazıyı ve biçimlendirmeyi aynı katmanda buluşturmayı olanaklı kılacak katışıklık erotiği dediğim şeyi gerçekleştiriyordu.

Rimbaud da - örnek bir yıkıcı avangard figürü olarak salt edebiyat kurumunun içine çekilmek üzere — bir parçalanma stratejisi, modern yaşam mitini kahramanca yaşamasına olanak sağlayan bir şiir şiddeti veya bir şiirde şiddet'i benimsiyordu. Sonuç olarak Rimbaud'nun tuhaf şiir şiddeti veya şiirde şiddet'i pek çok edebiyat araştırmacısının yorumunda bir şiddet poetikasına dönüşmenin eşiğindedir. Rimbaud'nun yaralı bedenini toptan yok etme eğilimi barindıran bir durumdur bu da.

Mayakovski-ister Fütürist bir sarı bluz, isterse Sovyet bronz ceket olsungöz alıcı atribüleri olan bir figür, yaşamı ile metni (tarz bakımından eklektik ve modern olsa dahi) tek bir melodram biçimini almış görünen bir şairdir. Mayakovski örneğinde, gündelik varoluşunun bütün unsurlarını önemli ve anlamlı kılmaya yönelik bir eğilim olan mahut metafor zorlantısını gözlemledik; bu da edebî intihar ile yaşamda intihar arasında tehlikeli bir bağlantı kurmamıza olanak sağladı.

Şairin siyasal bağlanımı ile toplumsal cinsiyetini birbiriyle ilişkilendirme sorunu (ki bunun en iyi örneğini devrimci şair ile şairede gördük, ama bu ikisiyle sınırlı bir sorun değildi bu), her ilişkiyi klasik retorik figürleri bağlamında görme girişimini daha da karmaşıklaştırmaktadır. Tsvetayeva özelinde, estetik müstehcenlik, duygu biçimciliği ve aşkın yapısı gibi görünüşte çelişki barındıran bazı terimleri ele aldım. Bu terimlerin hepsi de, Tsveyateva'nın eserleri veya yaşamı etrafında herhangi bir yorum filtresi oluşturmaya çalışırken karşılaşılan indirgenemez aşırılığı vurgulamaktadır. Buna rağmen yazmanın ve yaşamanın doğasına ilişkin en if̧̧a edici öngörüleri sunan da tam olarak bu aşırılıktır. ${ }^{50}$

Yaşam ve metin elbette ayrıştırılamaz bir bütün değildir ama birini ötekinden yalıtmak aradaki bağı görmezden gelmeyi gerektirebilir. Eğer yorumdan elde edilecek sonuç buna değecekse, bir metin incelemesi onu ortaya koyanın görüşlerinden bağımsız bir şekilde ele alınabilir ama tam tersi de doğrudur: Eğer bir metnin anlamı, onu ortaya koyanın maksadı veya yaşamının kimi ayrıntılarıyla daha anlamlı bir hale gelecekse niçin yaşamdan kaçalım ki? Boym'un alelalade bir metin eleştirisinden karmaşık ve ayrıntılı biyografi merkezli edebî eleştirisi bu bakımdan tam anlamıyla put kırıcıdır. Hem deha şair 
hem de ölü şair mitini yerle bir ediyor Boym. Yorum stratejisini yaşamdan, metni soluksuz bırakacak ölçüde izole etmediğimizde, kimi biyografik ayrıntıların metni biçimlendirici ögelerden biri olduğunu da görebiliriz. Türk şiirinde öyle örnekler vardır ki şairin ampirik varlığı bir gösterge olarak metne dönüşmüştür diyebiliriz. Başka bir deyişle "beden" ile "yazı", "hatıra" ile "metin", öyle iç içe geçer ki bunları birbirinden ayırdığımız takdirde anlam çöker; izole edilmiş metin âdeta anlamlandırılması için gerekli zemini yitirir. Bu şiirlerden biri İlhan Berk'in, “Ölü Bir Ozanın Sevgili Karısını Görmeye Gitmek” adlı şiiridir. Bu şiir Necatigil'in ölümü üzerine İlhan Berk'in, şairin eşi Huriye Necatigil'i ziyarete gitmesini anlatır ki şair bu hatıranın şiire nasıl kaynaklık ettiğini de yazmış; hatta bu hatıranın şiire nasıl dönüştüğünü mısra mısra açıklamıştır.

Yaşam ile şiir arasındaki sınırların kalktığını, şiirin kâğıt üzerinde âdeta nefes alıp vermeye başladığını görürüz bu şiirde. İlhan Berk'in Necatigil'in eşi Huriye Hanım'ın evine yaptığı ziyareti bir şiir haline getirmesi şiirin yaşamla olan bağının çarpıcı örneklerinden biridir. Şiirin adı, açıkça bir yaşantının doğrudan temsili olma iddiasındadır, bu yüzden şiirin bu bağlamın dışında yorumlanması eksik veya aşırı bir yorum olacaktır. Öyle ki şiirin adı edebî olanı yaşamsal olana doğru bir mıknatıs gibi çeker. Herhangi bir örtmece, şiire özgü retoriğin gerçekliği gölgelemesi veya bir yapıbozuma uğratması bu şiirin ağırlık merkezi değildir:

\section{Ölü Bir Ozanın Sevgili Karısını Görmeye Gitmek}

"Kâğitlar, kitaplar, dedi, nereye elimi atsam.

Kiminde yarım kalmış, nasılsa bitmiş bir şiir

Kiminde. Hem her şey şiirlerde değil miydi?

Bir gök şiirde ağar, bir sokak şiirlerde

Gider gelirdi.

$$
\text { Böyle yaşayıp gidiyorduk." }
$$

Sesi,

sanki çok ötelerden gelirmiş gibi

Ezik, suskun odaları dolaştı durdu.

Masada açık duran bir kitabı gösterdi sonra

Ölünün, son kez elini sürdüğü ve kaldığ1

"Burada işte oturmuş şu kitabı okuyordu, 
Elinden kitabın düştüğünü gördük sonra.

Hepsi bu."

Böyle dedi, yüzüne kapayıp ellerini

Alınmış gibi bir bulutun yer değiştirmesinden. ${ }^{51}$

İlhan Berk, bu şiirin oluşumunu anlattığ 1 yazısında, yaşantı ile retorik süreci birbirinden ayırır. Şiirin ilk dizesi, Necatigil'in eşi Huriye Hanım'ın bir sözüdür. Berk, ilk dizenin doğrudan yaşantıdan geldiğini, ardından, yaptığ1 ziyaretten edindiği izlenimleri teknik bir şiir çalışmasının potasında damıtarak öteki dizeleri nasıl bulduğunu anlatır. Berk, Paul Valéry'ye atıf yaparak şiir yazımında ilk ve en önemli işin ilk dizeyi bulmak olduğunu belirtir; ilk dize şairin zihnine düşüverir Valéry'e göre (Fr. une ligne donné; Ing. A given line); şiirin kalanı çalışmayla, yani retoriğe başvurularak yazılır. Berk de aynı sırayı izliyor ama onun zihnine ilk dize bir ilham eseri olarak gelmiyor; doğrudan Huriye Necatigil'in ağzından dökülüyor. Şöyle anlatıyor bunu Berk:

(Hepimizin bildiği gibi iki yıl önce Behçet Necatigil öldü. Ben Halikarnassos'daydım, cenazesine gidemedim. Benim yazdıkları en çok üstüne başına benzeyen ozan dediğim, o sevgili ozanlardandı Necatigil. Hiç kimseye yapmadığım şeyi ona da yapmadım: Başsağlığı dilemedim (Bu belki benim ölüm üstüne düşünmemden, belki de ölümleri anlamamdandır, bilmiyorum). Necatigillerin evi benim girip çıktığım—birkaç—sevgili evlerden biridir. Geçen yaz bir öğle sonu (cenazesi hâlâ kalkmamış gibi) büyük bir 1ssızlık içindeki apartmanın merdivenlerini çıktım, kapıyı çaldım. Issızlığın içinden açılan kapı, beni daha büyük bir ıssızlığa attı, bıraktı. Salonda her zamanki yerime oturup, sevgili karısının dönmesini beklemeye başladım. Elimdeki üç beyaz gülü masaya bıraktım. Ev, giden ölüyle doluydu sanki: Hiçbir eşya yerinden kımıldatılmamış, bir perde bile yerinden oynatılmamış, olduğu gibi duruyordu, görüyordum. Sevgili kedileri ezik, gelip bana süründü. Onca yaşama dolu eşi geldiğinde: Birden ölümü gördüm. Necatigil'in her zaman gördügüm odasını, ölümünden sonra da görmek istedim. Odaya girdiğimde her şey açıktı: Yoktu o. "İşte, dediler, hangi kitabı çeksem şiirler çıkıyor arasından!” Bir ozanın karısı, geride başka neler bulabilirdi ki? Onun da bulduğu onlardı. Çıktım. Necatigil'i, ölümü aşan bir şey kaldı bende. Sonra da her şey silindi gitti. Yeniden Halikarnassos'a döndüğümde, birden sevgili karısının sözleri gelip vurdu: işte hangi kitabı çeksem arasından şiirler çıkıyor! ${ }^{12}$

51 İlhan Berk, "Ölü Bir Ozanın Sevgili Karısını Görmeye Gitmek”, Toplu Şiirler, haz. Mehmet Taner, Fahri Güllüoğlu, İstanbul: Yapı Kredi Yayınları, 2008, s. 744.

52 İlhan Berk, “Ölü Bir Ozanın Sevgili Karısını Görmeye Gitmek”, Yazarın Kuramı, der. İshak Reyna, İstanbul: İletişim Yayınları, 2012, s. 314. 
Gerek dil kuramları gerekse edebiyat eleştirisinde bir metnin dış dünyadan bağımsız dilsel yapı ve düzenlemelerin bir ürünü olduğu yönündeki güçlü argümanlar, bu tür örnekler karşısında mevzi yitirebilir. Bu tür şiirler, somut yaşantı ile dilsel yaşantı arasındaki bağların sanıldı̆̆ kadar zayıf olmadığını gösterebilir. Bu şiir okura şunu kanıtlar: Bir sohbetin doğal akışında söylenen bir söz bir şiiri ortaya çıkaran ana fikir olabilir. "Ölü Bir Ozanın Sevgili Karısını Görmeye Gitmek” şiirinde retorik organizasyon Huriye Necatigil'in sözlerine bağlı bir şekilde gelişir; yani bir yaşantının doğal bir sonucudur bu retorik organizasyon. Eğer Berk'in anlattığı bu hatıra görmezden gelinirse, şiirin anlamsal bağlamı çöker.

\section{Anlamını Üreten Metin}

Metne odaklı edebiyat eleştirisi anlamın metnin dışından getirilmemesine özen gösterir. Yazar dışlanmıştır; okur da kendi varoluşunu metin arac1lığıyla sorgulamaktan men edilmiştir. Özgürleşen ne yazar ne okurdur, metindir bu yaklaşıma göre. Ama bu özgürlüğün temel bir sorunu vardır: Metin bir özne olmadığından kendi başına özgürleşemez; kendi arzularını dizginleyen bir okur tarafından özgürleştirilmek zorundadır; tabii buna özgürlük denirse. Bazı metinlerde, örneğin lirik şiirde, anlatım yoğunluğu esas olduğundan anlam boşlukları, eksiltmeler, kısaltmalar vardır; bu boşluklar kimi zaman yazarın bilinçli tercihidir ama çoğu zaman yazarın kontrolü dışında gelişir. Bu noktadan itibaren yazarın yetkesinden söz edilemez ama bu kez devreye okurun sınırsız yorumlama özgürlüğünü kısıtlayan rasyonalite ilkesi devreye girer ki Umberto Eco'nun yaptığ 1 da budur. Amaç metni kendi kendisiyle kontrol etmek, anlam üretimini metnin kendisine bırakmaktır; öyle ki okurun işlevi sadece, metnin üretebileceği anlamı kuvveden fiile çıarmak olsun. Eco'nun tasvip edebileceği türden bir metin odaklı yorumu, Behçet Necatigil'in "Kilim" başlıklı şiirini yorumlayan Mehmet Kaplan'ın incelemesinden yola çıkarak tartışabiliriz.

"Kilim", Behçet Necatigil' in anlam ile biçim arasında kurduğu kaynaşmay1 en iyi örnekleyen şiirlerden biridir. Mehmet Kaplan şiirin bu özelliğini öylesine yerinde gözlemlerle aktarır ki onun bu incelemesi Türk şiiri eleştiri tarihinde şiir ve biçim ilişkisi üzerine yapılmış nadir çalışmalardan biri olarak yerini alır. Şiirin 
anlamının biçimden çıkarılması Eco'nun metnin niyeti kavramıyla anlatmaya çalıştığ fikirle örtüşür. Eğer anlamı biçim belirliyorsa, okurun anlama katacağ1 fazladan bir yoruma ihtiyaç kalmaz. Şiirin biçimle kaynaşmış anlamı metindedir; eleştirmen bu anlamı sözcüklere en iyi döken kişidir öyleyse. Şiirdeki anlam boşlukları okurun dünyasından değil, metindeki imgeler arasında kurulan anlamlı bağlantılardan elde edilir. Tıpkı gökyüzündeki yıldızlara bakıp aralarındaki boşluklara çizgiler çekilerek elde edilen imgeler gibi. Anlamın kuruluşunda belirleyici olan şiirin okurda uyandırdığı anlam ufku değildir; belirleyici öge, metinde nesnel olarak var olan sözcüklerin (ve içlerindeki seslerin) anlam potansiyelidir. Kaplan, Necatigil'in bu şiirini yorumlarken metne bağlı bu anlam potansiyelini açığa çıkarmaya çalışmış. Önce şiire bakalım:

\section{Kilim}

Kilimde incir çekirdekleri-parlak, pahalı

Elmaslar yerine çekirdek — süs, avunma.

Hattâ soluk, ucuz boncuklar olabilirdi,

Cam boncuk, incir çekirdekleri-süs, avunma

Gezdir parmaklarını: Pürtük! Çünkü üzüm çöpleri

Aptallığımızdan kalma üzüm çöpleri, armut sapları

Ama biz dokuduk bu kilimi, eh bir dereceye kadar

Değil ele güne çıkacak, değil asılacak duvarlarda.

Çiğnenir—çok çiğ çağ—ayaklar altında yabansı.

Sağlam olabilirdi, saplar aldattı bizi:

Üzüm çöpleri, armut sapları, çekirdek, çok çiğ

Önceden düşünemedik, çok çiğ çağ!

Renkler, oldu bir kere, geçti, renkler

Düşünmek gerekti başlarken, sen buna

Renk mi diyorsun? Ben serin-mavi

Ismarlamıştım sana sıcak çaylar yanında.

Çok çiğ çağ. Çaldılar. Çıplak. Mavi, ama bu

Kan oturmuş tırnaklardaki mavi. Geçti.

Geçti, sökülemez, dokundu, sırıtır boşluk, ben sana..

Sakladığım baharlar nerde bu kilim için, 
Nerde yıllarca önce, ben sana..

Ne yaptın baharları, baharsız çok çiğg, topraklarda

Çok çiğ, çiçek—hiç yok—hani bu kilimde?

Hani beyaz, beyaz, beyaz,.. Beyazları ne yaptın?

Çok çiğ bu kızgın yaz, çiğ bu karakış!

Bâri biraz kışlarda.. Çıplak, çok çiğg!

Çok çiğ bu çığlık, bu en bol renk: Kara! Ben sana

Hiç kara koyma demiştim, nerden düştü, çok çiğ

Paslı borulardan katran, soba zifiri.

Sonra eski patiska perdeler gibi solgun ve siska

Parmaklarda kirli tütün sarısı.

Çok çiğ kesik öksürük, çĭg çatlak çağıltı!

En güzel renk mi, çok az! Eğreti, kaçamak, belki!

Belki kimi gecelerde ekleme

Sevinçlerden gelme çağla yeşili - - Yanlış!

Eğrelti otlarının yitik yeşili yâni,

İki başlı kartalların ölü gözlerinde-

—ki belki, çok az!

Sonra çok az pembe, işe giderken ayrılışlarda

Kimi günler bir süre hani ayaküstü

Çekingen bir gülüş, çekingen — çok çiğ çevre-

Pörsük-pembe, solgun güllerde, belki biraz!

Heyyy! Kilimdeki bu bir sürü merteğin

İşi ne? Çok çiğ! Kendi gözümüzde

Çöpler vardı, karartmış önümüzü.

Çöpler, yeterdi kilimde, bol—çok çiğ çağ-

Ama onlar mertek, doğru, çok çiğg!

Gözlerinin dalışı bile çok çiğg, çünkü - -

Çünkü hançer nakışlarda bu çılgın çağrı,

Bu çürük iplik, bu ensiz atkı,

Bizim! ${ }^{53}$ 
Kaplan metnin niyetini kurarken şiirin ses örgüsü, sözcük dağarcığı ve sözdiziminden hareket ediyor. Çıkış noktası metnin yapı özellikleri olduğu için metnin dışına çıkıp aşırı yorum yapma imkânı da kendiliğinden ortadan kalkıyor. Çünkü Kaplan, Necatigil'in bu şiirde ortaya koyduğu ses örgüsünden yola çıkarak şairin biçim ile içerik arasında kurduğu koşutluğa odaklanıyor. Böylelikle, metnin yapısına inmiş ve yorumunu da metnin yapısından elde etmiş oluyor. O yüzden Kaplan’ın “Kilim” incelemesi metin merkezli bir şiir yorumuna dönüşüyor. Kaplan’ın şiir incelemesi onun şu yorumuyla başlar:

Klâsik şairlerin tatlı ve ahenkli duyguları bestelemek için kullandıkları fonetik vasıtaları, Behçet Necatigil, 'ekspresyonist' bir üslupla çağın, insanı rahatsız edici gürültüleri haline getirir. Necatigil'in sadece duyan bir şair değil, aynı zamanda bir dil virtüozu olduğunu da gösteren bu şiiri, Türkçede, muhteva ile üslûp birliğini gerçekleştiren eserlerden birisidir. $^{54}$

Şiirde musiki dendiğinde klasik bakış açısının hep kulağa hoş gelen seslerin terkibi fikrinden hareket ettiğini biliyoruz. Tahir'ül Mevlevi'nin, Edebiyat Lügati'nde "aheng” kavramını açıklarken kullandığ 1 ilk cümle şudur: "Manzum, mensur bir sözün kulağa güzel ve pürüzsüz gelmesi, âdeta hafif tertip bir musikî te'siri yapmasıdır" 55 . Kaplan ise geleneksel belagatin "Kilim"deki tekniği incelemek için yeterli olmadığını görüp bu şiirde biçim içerik birliğinin kakafoni bağlamında kurulduğunu öne sürer: "Burada dikkati çeken özelliklerden birisi, şairin şiirinin mânasına uygun bir dil musikisinden faydalanmasıdır. Fakat bu musiki 'klasik' şiirde olduğu gibi, tatlı ve ahenkli değil, tam tersine, çarpıcı ve rahatsız edicidir" ${ }^{56}$. Şiir, başarısız bir sanatsal girişimden söz etmektedir. Şiirde konuşan kişinin, "göz alıcı bir kilim dokuyacaktık, niyetimiz buydu ama ortaya çirkin bir eser çıktı" dediği öne sürülebilir. Şiirde geçen "çok çiğ çağ” ifadesi, insanoğlunun bu çağda yaptığı şeyleri “çirkin” bulduğu, şairin "kilim”i modern çağın bir simgesi olarak kullandığı varsayılabilir. İşte bu görüşten hareketle Kaplan, şu yorumu yapar:

Şiir boyunca tekrarlanan "çok çiğ çă̆" kelimeleri, şiirin mânası ile beraber musikinin de anahtarını verir. Bu çağ, rahat, güzel, düzenli bir çağ değildir.

54 Mehmet Kaplan, "Dışarda”, Şiir Tahlilleri 2, İstanbul: Dergâh Yayınları, 2005, s. 198.

55 Tahir'ül Mevlevi, Edebiyat Lügati, İstanbul: Enderun Kitabevi, 1973, s. 17.

56 Kaplan, "Dışarda", s. 199. 
Tam tersine çirkinlikler, abeslikler ve çatışmalarla doludur. Şair, bu mânayı, hem çarpıcı semboller, hem fonetik oyunlar, hem de karışık, tereddütlü, girintili ve çıkıntılı bir sentaks ile belirtir. ${ }^{57}$

Biçim ile içerik arasındaki bu örtüşme dilin belli bir anlamı sadece dile getirmeyip aynı zamanda onu dilin dokusuna işlemesi, böylelikle bir tür mimetik etki yaratması, yani anlattığı şeye benzemesi demektir. Eğer sözcüklerin anlamı ile bu sözcüklerin ses ve görüntüsel içeriği arasında bir uyuşum yoksa mimetik etki gerçekleşmez. Bu yüzden konuyla ilgili temel çalışmalardan birinde yapılan şu vurgu önemlidir: "Sözcüklerin anlamsal içeriği mimetik potansiyeli açığa çıkarmak, ona odaklanmak zorundadır. Eğer anlamsal ögede böyle bir durum yoksa, sessel düzenleme çoğu durumda etkisiz kalır"s8. Necatigil'in şiirinde, Kaplan'ın belirttiği gibi, anlamsal öge sessel düzenlemeyle tam bir uyum içindedir. Bir tarafta şiirde anlatılan şeyler vardır. Başarısız bir sanat girişimidir bu. Göz alıcı bir kilim dokunmak istenmiş ama ortaya çirkin, zevksiz bir şey çıkmıştır. Anlam alegorik bir şekilde yorumlandığında, ideal bir dünya tasarımı düşlenmiş ama ortaya kaotik, insanı ezen bir dünya çıkmıştır. Öte tarafta ise şiirin anlam düzeyinde beliren bu zevksiz, çirkin, kaotik atmosferi taşıyan dil düzlemi vardır. Sözcük ve sözdizimi seçimi şiirin anlam düzeyine o denli uygundur ki şiirin dili anlamsal örgüyle kaynaşmış; anlamsal örgünün sessel bir dişavurumu haline gelmiştir. $\mathrm{Bu}$ durum kısaca bize şunu söyler: Kaplan, bu incelemesinde, metnin dokusuna odaklanarak bir yorum geliştirmiş; metnin dışına asla çıkmayarak, metnin sesleri ile anlamı arasındaki örtüşmeyi çözümlemiştir.

\section{Okur Özgür Kalırsa}

Okurun özgürlüğü metnin anlamı pahasına mı gerçekleşmelidir? Bu soru aslında yanıltıcıdır çünkü bir metnin anlamı veya anlamlarını ortaya çıkaran özne zaten okurdur. Eco gibi düşünecek olursak okurun belli bir rasyonalite içinde hareket etmesini beklemeliyiz ama akılcı ilkenin ölçütünü belirlemek de aşırı bir özgüven gerektirir. Bazı edebiyat eserlerinde öyle çapraşık, beklenmedik anlam bağlantıları bulunabilir ki akılcı ve sağduyulu davrandığını zanneden

57 Kaplan, "Dişarda”, s. 199.

58 Robert Beum ve Karl Shapiro, The Prosody Handbook: A Guide to Poetic Form, Mineola, New York: Dover Publications, INC., 2006, s. 15. 
bir yorumcu, bu anlam ilgilerini budayarak sıradanlığa düşebilir. Başka bir deyişle, rasyonel davranmak her zaman rasyonel olmayabilir çünkü bizim yorum ölçütlerimiz bu ölçütlerin çok ötesinde bir yoğunluk taşıyan metinleri sınayamaz. Yorumun belli ölçütlere bağlanmadan serbest bir düşünce eylemi, bir tür bilinç akışı olarak görülmesi "bilimsel" olmayabilir ama edebiyatın özgürlükçü ve hazcı doğasına uygundur. Bir sınama ölçütü olmadığında okurun anlamı yüzer gezer bir şey olarak kavraması kaçınılmazdır ki bunun sonuçları hem bir özgürlüğü hem de bir keyfiliği beraberinde getirir. Aşırı yorum veya aşırı anlama olarak adlandırılan bu okuma tarzı, bir edebî eserin zihnimizde uyandırdığg imge ve düşünceleri-pürüzlerini giderip ayıklamaksızın — dile getirmektir aslında. İmge ve fikirlerin traşlanıp bir heykel kıvamına getirildiğinde bir nesnellik görüntüsü kazanmaları daha olasıdır ama ham ve yeterince işlenmemiş imge ve fikirlerden de elde edilebilecek bir anlam genişliği, yok mudur?

Yorum ile aşırı yorum arasındaki farkı görebilmek için anlamı müphem bir şiire başvurmak yerinde olabilir. Bir şiirin anlaşılması ne kadar zor olursa düşünce gücümüz de o denli harekete geçer. Bu sayede sözcükler arasında alışılmadık anlam ilgileri bulmaya başlarız. Belki de zihnimizin bize oynadığı bir oyundur bu çağrışımlar ama böyle bir şiir karşısında tutarlı bir yorum yapmak da kolay bir iş değildir. Eğer şiirde birleştirilecek noktalar bulabildiysek, o şiirden duyulabilecek zihinsel hazzı yoğunlaştıran bir anlamsal bağlam üretme firsatı elde etmiş olabiliriz. Necatigil'in "Zar" adlı şiiri, dizeleri arasındaki anlam ilgileri kopuk bir metindir. Okur bu şiiri ilk kez okuduğunda afallayacak, bir anlam zemini bulabilmek için bu şiiri tekrar okumak isteyecektir. Eğer okur, yeterince istekliyse, vakti varsa, bu şiirdeki anlam uçlarını çeşitli deneylere sokup bir anlamsal bağlam üretmeye çalışabilir. Kısaca ifade etmek gerekirse, bir okur, bu şiiri bir oturuşta okuyup anlayamaz ama bu şiir üzerinde yoğunlaşıp anlam olasılıkları arama uğraşına girebilir. 


\section{Zar}

Hepsinin üzerinde pek de ince bir giysi

Ne zaman hatırlasam sanki bir şey unuttum

Sanki elimde idi sanki bırakıp gittim

Hepsi.

Bir sessizlik benimle gürültüye gitti

O bildiğim yerlere sanki bilmeden gittim

Sanki bir söz söyledim, de herkes işitti

Bir kapıyı yavaşça sanki çok hızlı ittim.

Öyle ince bir şey her şeyi gösteriyor

Sanki kendim giymişim düğmeleri ilikli

Şimdi çözemiyorum gittikçe dar geliyor

Bir kap1 - - sessizlik, işte bütün hepsi. ${ }^{59}$

Şimdi bir aşırı yorum denemesi yapılabilir: Şiir üçüncü halin olanaksızlığ ilkesinin ihlalini anlatmaktadır. Mantık, düşüncenin belli kurallarla işlemesidir. En bilinen mantık kurallarından biri, üçüncü halin olanaksızlığı ilkesidir. Bir şey ya o'dur ya da öteki'dir; bir insan ya ölüdür ya da diri; bu iki önermenin dışında, üçüncü bir olasılık yoktur. Şiir, hatırlamak ile unutmak, elde tutmak ile bırakmak, bilmek ile bilmemek, bir kapıyı yavaşça itmek ile çok hızlı itmek gibi birbiri ile çelişen eylemlerin aynı anda var olduğunu anlatmaktadır. Bu çelişkiler, sessizlik ile gürültü arasındaki karşıtlıkla desteklenir. Bu eylemlerin bir çelişki olduğunu gösteren zaman ilgisi, ikinci dizede verilmiştir. "Ne zaman hatırlasam sanki bir şey unuttum", çelişik eylemlerin aynı anda ortaya çıktı̆̆ izlenimini vermek için kurgulanmış gibidir. Bununla birlikte, şiirin bir felsefi metin olmadığı, belli bir argümanın sistematik savunusu olmadığı da aynı şekilde geçerlidir. Şiir boyunca tekrar eden "sanki" edatı, bu şiirin çelişik yapısına uygun değildir; sonradan eklenmiş gibidir; öyleyse bu edatın şiirde var olmasının ancak iki anlamı olabilir: "Sanki", hem şiirin bir önermeler listesi olmasını önler hem de metne müzikal bir hava verir. "Zar" şiiri bu yüzden iki türlü okunmalıdır. Bir okur, "sanki" edatını muhafaza ederek bu şiiri melodik bir şekilde okuyabilir; bir başka okur ise şiirin çelişik felsefi anlamını çözmek 
için bu şiiri "sanki" edatını atarak okuyabilir. Yorumcu bir kez bu yola girdiğinde şiirdeki her işareti bu bağlama çekecektir. Böylelikle şiirin son dizesinde (- -) çizgi ile belirtilen boşluk da yoruma dahil edilir: Bu şekilde, "şiirden kesilip çıkarılan "sanki"nin bıraktığı bir izin görsel imgesidir bu çizgiler" iddiası bile öne sürülebilir. Hatta yorumcu daha da ileri giderek "sanki" edatının üstünü felsefi bir gerekçeyle çizdiğini öne sürüp felsefeyle ilgilenen okurlara Martin Heidegger'in Metafizik Nedir? kitabını hatırlatarak ${ }^{60}$ bu yorumuna bir felsefi meşruiyet kazandırmaya da çalışabilir.

Bu çözümleme, ilk bakışta, Necatigil'in şiirlerini anlamaya yönelik felsefi bir girişim olarak görülebilir. Yorumun çıkış noktası, şiirde mantıksal açıdan tutarsız görünen dizelerdir. Şiiri okurken, gerçekten de bu dizelerin bir çelişkiyi vurguladığı düşünülebilir. Bu nedenle bu yorum, geçerli bir zemine dayanıyor gibi görünür. Oysa daha yakından bakılırsa, okurun sözcüklere dokunup kendi anlam dünyasına kaçtığını, şiiri derinlemesine irdelemek yerine, şiirden aldığı bir izlenimi derinleştirdiğini anlarız. Öncelikle bu yorumun, Eco'nun deyişiyle iktisadi olmadığını vurgulamak gerekir çünkü okur, yoruma uymayan dizeleri ileri sürdüğü argümanın dışında tutmuştur. Şiirin bazı dizelerinde, yorumcunun iddiasını destekleyecek tutarsızlıklar bulmak mümkündür ama her dizede değil. "Bir sessizlik benimle gürültüye gitti” dizesinde örneğin, sessizlik ile gürültü arasında bir karşıtlık vardır kuşkusuz ama sözcük düzlemindeki bu karşıtlık semantik düzlemde bir karşıtlığa yol açmaz. Sessizliğin gürültüye gitmesi bir deyimdir ve sessizliğin bir sebepten ötürü kaynayıp gitmesi, tadının çıkarılamaması anlamına gelir. Bunun yanı sıra, "Sanki bir söz söyledim, de herkes işitti" dizesinde de, yorumcunun "Ne zaman hatırlasam sanki bir şey unuttum" dizesinde gördüğü türden bir tutarsızlık yoktur ki aynısı "Sanki kendim giymişim düğmeleri ilikli” dizesi için de geçerlidir. Bu yüzden yorum şiiri açmaktan çok kendi argümanını desteklemek için argüman üreten bir metne dönüşür. Çünkü şiirin üçüncü halin olanaksızlığı ilkesinin ihlalini anlattığı fikri ortaya atılmıştır bir kez; artık arkadan gelen yorumlar sadece bu ana fikri desteklemek için kurgulanır. İşte bu nedenle yorumcu, "sanki" edatının şiirdeki

60 Martin Heidegger, Metafizik Nedir? kitabında varlık felsefesi yaparken bazı kavramların belirsizliğini bu yolla aşmaya çalışır. "Varlık" gibi bazı temel kavramlar anlatmak istediği içeriği iletmede yetersizdir ama yine de gereklidir bu kavramlar. Bu yüzden Heidegger bu tip sözcüklerin üstüne bir çarpı atar ama bu sözcük yine de oradadır, çarpının altından görünür. Bk. Martin Heidegger, Metafizik Nedir?, çev. Yusuf Örnek, Ankara: Türkiye Felsefe Kurumu, 2009, s. 9, 11 vd. 
işlevi hakkında manipülatif gerekçeler üretmek zorunda kalmıştır. Şiir bir kenara bırakılmış; yorumcu kendi yorumu için şiirden gerekçeler üretme çabasına girişmiştir. "Sanki” nin bu şiirin çelişki üreten anlam örgüsüne ait olmadığ düşüncesini ortaya çıaran da bu girişimdir. Buna göre "sanki" hem şiirdeki çelişkileri örtbas etme hem de şiire melodik bir üslup kazandırma amacı taşır. "Sanki”nin üstünü çizip şiiri yeniden okursak metnin altında yatan çelişkilere ulaşabiliriz. Çözümlemenin bu ısrarcı tutumuna rağmen, bu şiirde tutarsız gibi görünen eylemlerden üçüncü halin olanaksızlığı ilkesinin ihlali sonucunu çıkarmak bir aşırı yorum örneği olarak görülebilir. Niçin?

Orhan Koçak'ın bu şiir hakkındaki yorumu bu sorunu çözüyor. "Zar" şiirinde çatış1k konunun baştan sona sürdüğünü vurgular Koçak ama bu çatış1klığın bir çelişki olmadığının da altını çizer: "Ama bu çelme, toptan bir iptal sonucunu doğurmaz; ilk adımın vaadi (ya da özlemi, isteği, güveni, bilgisi) ikinci

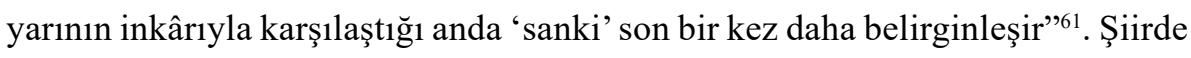
"sanki”ye yapılan vurgunun çokluğu bu ifadeyi görmezden gelmek yerine, onu şiirin tamamı için belirleyici bir öge olarak değerlendirmeyi gerekli kılar, en azından Eco'nun vurguladığı gibi yorumda iktisadi olmanın bir gereğidir bu. Yoruma bu ilke gereği, "sanki”yi atılacak bir safra olarak görmeden başladığımızda, şiirdeki tutarsızlıklar, şiirde konuşan kişinin bir faraziyesine, bir sanısına dönüşür. Bilişsel körlük veya bilinç kaybı yüzünden olayların oluş sırasını kestiremeyip tedirgin bir ruh haliyle kendi kendine sayıklayan bir şiir karakteri olabilir bu kişi.

Burada, bu şiirin aşırı olmayan bir yorumunu yapacak değiliz ama şunu vurgulamak gerekir ki her metin merkezli yorum albenili olmayabilir. Metni kullanarak yapılan çarpıcı çıkarımlar, metin merkezli bir yorumdan çok daha cazip olabilir ama okurun metinle ne yapmak istediğiyle ilgili bir sorundur bu. Okur, metni daha anlaşı1ır kılmak $\mathrm{m}$ istiyor yoksa metni kullanıp ortaya insanın aklını alan, onu şaşırtıp eğlendiren yorumlar mı yakalamak istiyor? Okurun özgürlük alanının sınırlarıyla ilgili bir konudur bu. Eğer okur özgür bırakılacaksa, yorumun geçerliliğini katı bir şekilde sınamak anlamına gelen iktisadi ilke gevşetilebilir. İster aşırı yorum, ister yetersiz yorum, isterse aşırı anlama olarak 
adlandırılsın, okurun yönelimine tanınan bu gevşemenin sonuçları, biraz manipülatif, biraz sansasyonel olacaktır kuşkusuz.

\section{Sacayağını Onarmak}

Metin eleştirisinde belli bir eğilimin ağırlık kazanması bu eğilim dışındaki görüşleri sahnenin dışına kolaylıkla itebilmektedir. Yeni Eleştiri'nin şiir yorumunda yazarı devre dışı bırakması, Umberto Eco'nun okurun yorum özgürlüğüne sınırlar çizip onu kontrol altında tutmaya çalışması kendi içinde tutarlı bir fikrî alt yapıya sahiptir. Ancak hem bu görüşler çokça eleştiriye maruz kalmıştır hem de uygulama alanında işlemediği noktalar görülebilmektedir. Edebiyat kuramlarının sorunlarından biri, uygulama alanında her zaman işlevsel olmamasıdır. Yeni Eleştiri, anlam konusunda müphem, lirik şiirlerin anlaşılmasını tutarlı ve sağlam bir çizgiye çekmiştir ancak anlam yönünden kapalı olmayan, şairin biyografik özellikleriyle bağları tartışılamayacak ölçüde açık olan şiirler karşısında bu kuramsal yaklaşımın gücü yiter. Benzer şekilde Umberto Eco'nun okurun yorum gücüne sınırlar çizmeye çalışması, metin karşısında bir özne durumunda olan okurun anlama ve yorumlama uğraşı sırasında devreye soktuğu zihinsel iradeyi yok sayma eğilimi taşır. Bir okur, yorum sırasında, neyin aşırı neyin anlama sınırları içinde olduğuna karar verirken o âna kadar geliştirdiği zihinsel kapasiteye dayanır. Bir yorum anlama sınırlarını zorlayabilir, mantık dışı bir noktaya kayabilir ama bu kusur, anlama ve yorumlamanın standart ölçüleri olduğu anlamına gelmez. Metnin bir bölümünü aydınlatan bir yorum, o metnin geri kalanıyla uzlaşmak zorunda olmayabilir. Çünkü edebi metinlerin anlam örgüsünün her zaman sağlam, iç yapısının her zaman tutarlı olduğunu iddia etmek metinlerin romantikleştirilmesinden başka bir şey değildir. Öte taraftan okurun tamamen özgür bırakılması, okurun anlam dünyasının metni açıp dönüştürmek yerine bir manipülasyona uğratması anlamına da gelebilir. Ama şurası da bir gerçektir ki bir metnin yeterince iyi yorumlanmadığını sınayacak kişi de bir başka okurdur. Başka yorumları ölçüp biçip metnin haklarını savunacak olan da bir okurdur. İşte bu yüzden metinlerin incelenmesinde, yazar ve okur gibi öznelerin mutlak surette dışlanması her zaman doğru sonucu vermeyebilir. 


\section{Kaynakça}

Ahmet Haşim. "Şiir Hakkında Bazı Mülâhazalar". Ahmet Haşim: Bütün Eserleri. Haz. İnci Enginün ve Zeynep Kerman, İstanbul: Dergâh Yayınları, 2013.

Barry, Peter. Beginning Theory: An Introduction to Literary and Cultural Theory. Manchester ve New York: Manchester University Press, 2009.

Barthes, Roland. "The Death of The Author”. Image, Music and Text. Londra: Fontana Press, 1977.

Belge, Murat. Şairaneden Şiirsele: Türkiye'de Modern Şiir. İstanbul: İletişim Yayınları, 2018.

Berk, İlhan. “Ölü Bir Ozanın Sevgili Karısını Görmeye Gitmek”. Toplu Şiirler. Haz. Mehmet Taner, Fahri Güllüoğlu. İstanbul: Yapı Kredi Yayınları, 2008.

Berk, İlhan. “Ölü Bir Ozanın Sevgili Karısını Görmeye Gitmek”. Yazarın Kuramı. Der. İshak Reyna, İstanbul: İletişim Yayınları, 2012.

Beum, Robert ve Karl Shapiro. The Prosody Handbook: A Guide to Poetic Form. Mineola, New York: Dover Publications, INC., 2006.

Boym, Svetlana. Tırnak Iç̧inde Ölüm: Modern Şairle İlgili Kültürel Mitler. Çev. Emine Ayhan, İstanbul: Metis Yayınları, 2010.

Buchbinder, David. Contemporary Literary Theory and the Reading of Poetry. Melbourne: The Macmillan, 1991.

Culler, Jonathan. “Aşırı Yorumun Savunusu”. Yorum ve Aşırı Yorum. Çev. Kemal Atakay. İstanbul: Can Yayınları, 1997.

Eagleton, Terry. Edebiyat Kuramı: Giriş. Çev. Tuncay Birkan, İstanbul: Ayrıntı Yayınları, 2004.

Eco, Umberto. Açık Yapıt. Çev. Pınar Savaş. İstanbul: Can Yayınları, 2001.

Eco, Umberto. "Metinleri Aşırı Yorumlama". Yorum ve Aşırı Yorum. Çev. Kemal Atakay. İstanbul: Ayrıntı Yayınları, 2016: 53-74.

Eco, Umberto. "Yorum ve Tarih". Yorum ve Aşırı Yorum. Çev. Kemal Atakay. İstanbul: Ayrıntı Yayınları, 2016: 31-52.

Frye. Northrop. Anatomy of Criticism. New York: Atheneum, 1966.

Heidegger, Martin. Metafizik Nedir? Çev. Yusuf Örnek. Ankara: Türkiye Felsefe Kurumu, 2009.

Memet Fuat. Nâzım Hikmet: Yaşamı, Ruhsal Yapısı, Davaları, Tartışmaları, Dünya Görüşü, Şiirinin Gelişmeleri. İstanbul: Adam Yayınları, 2006.

Göksu, Saime ve Edward Timms. Romantik Komünist: Nâzım Hikmet'in Yaşamı ve Eseri. Çev. Barış Gümüşbaş, İstanbul: Doğan Kitap, 1999. 
Hartman, Geoffrey H. Easy Pieces. New York: Columbia University Press, 1985.

Kaplan, Mehmet. "Dışarda”. Şiir Tahlilleri 2. İstanbul: Dergâh Yayınları, 2005.

Koçak, Orhan. Kopuk Zincir: Modern Şiir Üzerine Denemeler. İstanbul: Metis Yayınları, 2012.

Necatigil, Behçet. "Kilim”, Bütün Eserleri. Haz. Murat Yalçın. İstanbul: Yapı Kredi Yayınlar1, 2013.

Necatigil, Behçet. “Zar”. Bütün Eserleri. Haz. Murat Yalçın. İstanbul: Yapı Kredi Yayınları, 2013.

Okay, Orhan. Poetika Dersleri, Ankara: Hece Yayınları, 2005.

Rorty, Richard. "Pragmatistin Yolculuğu". Yorum ve Aşırı Yorum. Çev. Kemal Atakay. İstanbul: Ayrıntı Yayınlar1, 2016: 98-119.

Saussure, Ferdinand de. Course in General Linguistics. Trans. Wade Baskin. New York: Philosophical Library, 1959.

Süreya, Cemal. “Şairin Hayatı Şiire Dahil”. Folklor Şiire Düşman. İstanbul: Can Yayınları, 1992.

Tahir'ül Mevlevi. Edebiyat Lügati. İstanbul: Enderun Kitabevi, 1973.

Urgan, Mina. İngiliz Edebiyatı Tarihi. İstanbul: Yapı Kredi Yayınları, 2008.

Valéry, Paul. "Deniz Gömütlüğü Konusunda”. Çev. Orçun Türkkay, Yazarın Kuramı: Eserimi Nasıl Yazdım. haz. İshak Reyna, İstanbul: İletişim Yayınları, 2012.

Wimsatt, Jr. W. K. “Affective Fallacy”. The Verbal Icon. University of Kentucky Press, 1954: 21-39.

Wimsatt, Jr. W. K. “The Intentional Fallacy”. The Verbal Icon. University of Kentucky Press, 1954: 3-18 